\title{
Forecasting the trajectory of electric vehicle sales and the consequences for worldwide $\mathrm{CO}_{2}$ emissions
}

\author{
Nele Rietmann*, Beatrice Hügler, Theo Lieven \\ University of St. Gallen, Institute for Customer Insight, Bahnhofstr. 8, CH-9000, St. Gallen, Switzerland
}

\section{A R T I C L E I N F O}

\section{Article history:}

Received 9 September 2019

Received in revised form

26 February 2020

Accepted 9 March 2020

Available online 19 March 2020

Handling editor: Giorgio Besagni

\section{Keywords:}

Electric vehicles (EVs)

Logistic growth model

Sales prediction

Market share

$\mathrm{CO}_{2}$ emissions

Cross-national

\begin{abstract}
A B S T R A C T
Over the past decade, global sales of electric vehicles (EVs) have experienced significant growth. However, predictions of future sales developments, which are needed for the planning of EV production as well as supporting policies and a sufficient energy supply, are still sparse. In this study, a long-term forecast of the EV inventory in 26 countries across five continents is provided by means of a logistic growth model. Using actual sales data from 2010 to 2018, predictions were made for these countries until 2035. Findings indicate that, overall, 30\% of the worldwide passenger vehicle fleet will be EVs in 2032. However, results also display vast differences between countries, which can particularly be attributed to divergences in governmental support. EV growth predictions were additionally analyzed in terms of sustainability impacts. The analysis showed that reductions in $\mathrm{CO}_{2}$ emissions can be achieved with the predicted EV growth, given that countries invest heavily in renewable energy sources. Given the current energy mixes though, worldwide $\mathrm{CO}_{2}$ emissions will continue to rise until 2035 despite a nearly $50 \%$ share of EVs. The paper further discusses the amount of energy that will be required to meet the growing demand and highlights that the production of EV batteries will be the key bottleneck in the development of EVs. Finally, important implications for policymakers, marketers and future research are derived.
\end{abstract}

(C) 2020 Elsevier Ltd. All rights reserved.

\section{Introduction}

The development of the market for electric vehicles (EVs) has gained increasing attention by policymakers and consumers over the past years, especially due to their potential to reduce greenhouse gas (GHG) emissions (Ellingsen et al., 2016). Yet, it is still unclear how exactly this trend will evolve in the future (IEA IA-HEV, 2018; Rezvani et al., 2015). Predicting EV sales over time is key for various stakeholders, including automobile producers, policymakers, and energy providers, to plan the production of EVs, set appropriate policies, and deliver a sufficient energy supply (Eggers and Eggers, 2011; Higgins et al., 2012). Furthermore, it is not clear how the reduction in the fleet of combustion chamber engines (ICEs) burning fossil fuels and the increase in the EV fleet will affect $\mathrm{CO}_{2}$ emissions. The present study aims to provide a long-term forecast of the EV inventory in 26 countries across five continents and examines its implications on environmental sustainability, particularly carbon dioxide $\left(\mathrm{CO}_{2}\right)$ emissions due to their high impact on global warming (Florides and Christodoulides, 2009; Shakun et al., 2012).

Prior studies have already proposed means to estimate the EV

\footnotetext{
* Corresponding author.

E-mail addresses: nele.rietmann@unisg.ch (N. Rietmann), beatrice.huegler@ unisg.ch (B. Hügler), theo.lieven@unisg.ch (T. Lieven).
}

market penetration. This includes stochastic models based on consumer preferences, such as discrete choice or agent-based models, and models depicting the diffusion of innovations, such as exponential or logistic growth models (Al-Alawi and Bradley, 2013; Geroski, 2000). Consumer preference models are useful to illustrate decision-making, purchase motives and potential barriers (Lieven et al., 2011). Nonetheless, they are less transparent than diffusion models and the underlying data often do not accurately depict actual demand (Geroski, 2000; Gnann et al., 2015). Moreover, they typically only represent behavior at one point in time (Qian and Soopramanien, 2014).

In contrast, diffusion models describe the development of products' market acceptance over time and are particularly useful if there are already sales data available (Al-Alawi and Bradley, 2013; Qian and Soopramanien, 2014). These models also have some drawbacks, including the need to endogenously estimate the peak of sales and the ultimate market potential. Diffusion models are, however, comparatively easy to implement and can be based on historical data of the innovation or a similar product (Al-Alawi and Bradley, 2013). Moreover, their relevance for EV predictions has been demonstrated in prior studies (e.g., Jensen et al., 2017; Massiani and Gohs, 2015).

Although various models have been developed to forecast EV diffusion, they have almost exclusively focused on individual countries. The current study investigates EV growth in 26 countries across 
five continents using a logistic growth model. This allows comparing national differences and predicting EV sales in late-adopting countries with data from early-adopting countries (Meade and Islam, 2006). Moreover, this study evaluates sustainability implications of the predicted EV growth. This has not yet been examined in previous research forecasting EV sales, despite the ever-increasing relevance and prevalence of this issue (Faria et al., 2013; Huo et al., 2015; Wu et al., 2018).

In the following analysis, the term EV refers to both full battery electric vehicles (BEVs) and plug-in hybrid electric vehicles (PHEVs). The consolidation of these two categories seems appropriate as BEVs are expected to replace PHEVs in the long-term, as indicated by recent trends (EV-Volumes, 2019). Hence, it is assumed that consumers who were willing to acquire a PHEV will soon switch to BEVs. As the focus is on consumers' EV adoption, only passenger cars are considered, referring to road motor vehicles carrying up to nine passengers (OECD, 2013). Moreover, this study's calculations are based on data from 2010 to 2018 when the EV market had a clear uptrend. We concentrate on $\mathrm{CO}_{2}$ emissions from ICEs and EVs during their use phase and do not consider production-based $\mathrm{CO}_{2}$ emissions to avoid overcomplexity.

Conceptually, we start with the predicted growth of the vehicle fleet for all countries. Each country has its own limit at which the demand for vehicles is saturated. Based on this limit, existing data on EV sales from 2010 to 2018 will be used to estimate an EV inventory growth in each country, thereby estimating the total vehicle fleet of ICEs and EVs in 2035. We calculate $\mathrm{CO}_{2}$ emissions in 2018 based on each country's electricity mix and compare them with the total vehicle fleet of ICEs and EVs that are predicted by our growth model in 2035.

In what follows, growth models and the impact of EV growth on sustainability will firstly be discussed in more detail. Afterwards, a logistic growth model is applied to forecast EV sales in 26 countries until 2035. Furthermore, implications of the predicted EV growth will be discussed, particularly on $\mathrm{CO}_{2}$ emissions as well as the required energy and battery production.

\section{Logistic growth models}

To forecast the diffusion of innovations, various growth models have been developed since the 1960s (Meade and Islam, 2006). Most models employ a logistic or other S-shaped function to depict innovation adoption over time (Muller and Mahajan, 1979). Some scholars argue that this shape represents the population's dynamics, analogous to an epidemic. Alternatively, it has been proposed that individuals simply have different, normally distributed thresholds for adopting new products (Meade and Islam, 2006). Both explanations make this type of curve particularly suitable to explore long-term EV adoption.

Various studies have already successfully employed logistic models to forecast innovation sales. For example, Boretos (2007) uses such a model to predict the number of active mobile phone accounts in China and Europe until 2010 based on existing data from 1992 to 2004. Overall, results display high accuracy and a high coefficient of determination. Similarly, Yang and Williams (2009) forecast sales of obsolete computers in the United States (USA) until 2050 with a logistic model using sales data from 1978 to 2008. To and Lee (2014) later confirm the results' validity. Furthermore, Qian and Soopramanien (2014) applied a Gompertz model, a logistic model, and a Bass model to predict car sales in China. The former two are also explored in an extended version, which additionally includes time and GDP. Results indicate that the extended logistic growth model is the most accurate forecast model for car sales as it provides the smallest median and mean values of performance metrics.

In sum, several studies accurately forecast product sales with the logistic growth model. In all cases, results are examined regarding their plausibility. Models with maximum and minimum parameter levels allow for potential uncertainties caused by external factors such as economic changes and natural catastrophes (Bloom, 2014). Forecasts also have to be adjusted when results significantly exceed realistic predictions. Taking this into account, the logistic growth model is a suitable EV sales predictor.

\section{Impact of EV growth on sustainability}

The predicted EV growth has important sustainability implications, as indicated by previous research. Wu et al. (2018) used the lifecycle analysis (LCA) method to analyze GHG emissions of BEVs and conventional internal combustion engine (ICE) cars in China in 2010, 2014 and 2020. They find that total lifecycle GHG emissions of EVs will gradually decrease over time, compared to ICEs, and that BEVs may provide long-term environmental benefits, especially if the electricity mix is improved. Further LCA studies draw similar conclusions (e.g., Faria et al., 2013; Huo et al., 2015).

Moreover, Casals et al. (2016) examined EV emissions compared to ICEs on a national scale across Europe, based on electric power plant fleet and use-phase efficiency. Their results indicate that some countries (e.g., Norway, Sweden) are better suited for EV adoption and that others (e.g., Germany, UK) will need to adapt their electricity mix in order for environmental benefits to show over time. Similarly, Nanaki and Koroneos (2013) argue that environmental improvements of EVs would be enormous if carbon-free electricity was used.

Furthermore, environmental impacts of EVs' production and operation phases have been discussed. According to Ellingsen et al. (2016), EVs' production phase is more environmentally costly compared to ICEs'. However, they argue that this is over-compensated in the use phase. Onat et al. (2014) also find that the operation phase has the highest environmental impact, leading to a total advantage of EVs over ICEs. Overall, $\mathrm{CO}_{2}$ emissions from an EV fleet have been shown to potentially be 10-26 times lower than those from an ICE fleet (Teixeira and Sodré, 2018). This result is based on the assumption of a $5 \%$ annual increase in $\mathrm{CO}_{2}$ emissions and the neglect of a possible increase in ICE efficiency, which could reduce $\mathrm{CO}_{2}$ emissions.

Global EV growth may also cause some issues. Firstly, increased EV usage may impact grid stability due to excessive demand for electricity (Dharmakeerthi et al., 2014). Concomitantly, there will be a potential overload of distribution lines and increased power system losses (Pieltain Fernández et al., 2011). Secondly, the production of EV batteries depends on raw materials including rare earths (Egbue and Long, 2012). The necessity of certain raw materials leads to growing concerns about resource scarcity and dependency on suppliers, potentially resulting in a vulnerability of the industry (Ziemann et al., 2013).

Nevertheless, a growing EV inventory worldwide is expected to have substantial positive implications on global environmental sustainability. In this study, a long-term analysis will be provided based on the proposed growth model.

\section{Methodology}

\subsection{Selection of growth model}

To develop the logistic growth model, data was collected from secondary sources for 26 countries (see Table 2). They were selected because they are among the OECD or BRICS countries representing five continents overall, for which relevant data was available. Hong Kong and Taiwan were additionally included due to their strong growth in the gross domestic product (GDP) over the past decades (Government of Taiwan, 2019; The World Bank, 2019). For all countries, the following existing data for 2010 to 2018 was 
Table 1

Vehicle inventory in China (in 1000 units).

\begin{tabular}{|c|c|c|c|c|c|c|c|c|c|c|c|c|c|c|}
\hline Year & 2005 & 2006 & 2007 & 2008 & 2009 & 2010 & 2011 & 2012 & 2013 & 2014 & 2015 & 2016 & 2017 & 2018 \\
\hline Total & 21,325 & 26,196 & 31,960 & 38,389 & 48,451 & 61,634 & 74,850 & 87,376 & 101,361 & 117,482 & 135,805 & 156,772 & 178,031 & 198,421 \\
\hline EVs & & & & & & 1.111 & 5.292 & 16.907 & 30.773 & 94.486 & 284.212 & 655.543 & 1303.980 & 2465.753 \\
\hline
\end{tabular}

Sources: OICA (2019), Statista (2019), EV-Volumes (2019).

used: Total car inventory (MarkLines, 2019; OICA, 2018; Statista, 2019), EV inventory, EV market share, annual EV sales, and EV sales growth (EV-Volumes, 2019). This was required for the prediction of future sales for 2019-2035.

China served as an example to demonstrate the prediction procedure. The country was selected as it currently represents the largest car market worldwide. Moreover, in terms of EV growth so far China is no significant outlier. Using countries such as Norway with an already large base or Australia with a small base of existing EVs to demonstrate the prediction procedure would be less appropriate than China with its significant growth. Initially, the saturation limit of all car inventories was predicted via a logistic growth model using the total passenger car inventories from 2005 to 2018. It was assumed that this limit is identical with that for EVs. This limit and the actual EV sales from 2010 to 2018 served to estimate a logistic growth function for EVs in China.

The initial growth function was amended by a second growth function with a flatter curve. This ensured that predicted sales did not substantially exceed yearly ICE sales. Accordingly, a predictive calculation with actual data was computed with the logistic growth model for all remaining 25 countries. For these countries, a forecast for total car inventory, EV inventory and EV sales was determined. To test the results' robustness, sensitivity analyses were conducted by repeating the procedure with sales data from (1) 2010-2015, (2) 2010-2016, and (3) 2010-2017, as well as adjusting the saturation limit.

Not all factors influencing EV sales can be predicted over the longterm, including technological advancements, GDP growth and policy measures. These are, however, implicitly included in the model as maximum and minimum parameters account for such external uncertainties (Bloom, 2014; To and Lee, 2014). Moreover, it needs to be noticed that national purchasing power is an important factor influencing the growth of a country's EV fleet as it increases the effects of public policy measures to promote electric mobility (Rietmann and Lieven, 2019).

\subsection{Calculation of $\mathrm{CO}_{2}$ emissions and electricity demand}

To calculate sustainability impacts, this study focused on $\mathrm{CO}_{2}$ emissions during car usage as this is the crucial phase regarding longterm emissions (Ellingsen et al., 2016; Onat et al., 2014). For each country, the following data were collected from secondary sources: ICE fuel consumption per $100 \mathrm{~km}(\mathrm{~km}), \mathrm{CO}_{2}$ emissions per km, EVs' average energy used per $\mathrm{km}, \mathrm{CO}_{2}$ emissions per $\mathrm{kg}$ from electricity production (based on current energy mix), and average distance travelled annually by car. Details and references are summarized in Table 2 and Appendix D. Calculations differed between ICEs and EVs. For ICEs, about $2.45 \mathrm{~kg}$ of $\mathrm{CO}_{2}$ are assumed per liter, given a mixture of gasoline and diesel engines (IPPC, 2014). As cars have different fuel consumptions across countries, lge (liters gasoline equivalent) per $100 \mathrm{~km}$ and gram $\mathrm{CO}_{2} / \mathrm{km}$ data were collected from the International Energy Agency (IEA, 2019a). On average, EVs need $0.185 \mathrm{kWh} / \mathrm{km}$ (Electric Vehicle Database, 2019). Furthermore, each country has a different energy mix and thus, $\mathrm{CO}_{2}$ emissions from electricity generation $(\mathrm{g} / \mathrm{kWh}$ ) were determined individually from 2014, for which data is available (OECD, 2019, Table 2). Table 2 compares $\mathrm{CO}_{2}$ emissions of the total car fleet in 2035-2018. Moreover, a comparison is made to a scenario, in which all passenger cars are assumed to be ICEs in 2035. The rule of ceteris paribus applies here: It is assumed that in 2035 carbon intensity of electricity generation (column 5 in Table 2) and EV electricity consumption $(0.185 \mathrm{kWh} / \mathrm{km}$; Electric Vehicle Database, 2019) will be the same as in 2018.

The subsequent calculation of the EV electricity demand in 2035 was performed by multiplying each country's predicted EV inventory with the energy required for an EV annually, given an average mileage of 17,000 km (Electric Vehicle Database, 2019, Table 2). The resulting figure was compared to the total electricity production in 2017 (Dudley, 2019).

\subsection{Modelling the EV inventory}

The model of the EV inventory forecasts is based on a logistic growth function. Growth increases slowly in the beginning, then more rapidly, and finally more slowly again after the inventory has passed the inflection point and reaches the saturation limit(see Fig. 1).

The logistic growth function is:

$I(t)=\frac{L}{1+\left(\frac{L}{I(0)}-1\right) \cdot e^{-k \cdot L \cdot t}}$

with $I(t)=$ Inventory at time $t, L=$ Saturation Limit, $I(0)=$ Inventory at the beginning $(t=0), k=$ growth factor.

The predicted EV sales for the 26 countries were determined with the following procedure:

a) Estimate the saturation limit $L$ which is the maximum expected number of all passenger vehicles in the country.

b) Estimate a logistic growth function with $L$ and actual EV sales in recent years. ${ }^{1}$ This is done by calculating a trend line that fits a curve to existing data, leading to a function - in this case a logistic growth function. This results in the parameters $I(0)$ and $k$.

c) Adjust EV growth functions according to the existing market potential of total annual car sales.

The procedure is demonstrated with data from China, where about 200 million passenger cars were in use at the end of 2018, compared to 21 million at the end of 2005 . Thus, the vehicle inventory has increased tenfold within 13 years. Significant EV sales started in 2010, although only 1,111, which increased to 2.47 million in 2018. Table 1 displays China's inventory figures.

In a first step, total inventories were predicted by a logistic growth function using actual total car inventories from 2005 to 2018 (Table 1). For China, this resulted in a predicted upper limit $L=355$ million to be reached in 2060. The symmetric growth function has its inflection point in 2015 with about 175 million units (Function I, i.e. (I) Total Inventory, Fig. 2). Fig. 2 displays the passenger car inventory until 2060, as this is when the saturation limit is predicted to be reached.

Using $\mathrm{L}=355$ million and actual EV inventories from 2010 to 2018 (Table 1) for a logistic growth function resulted in $I(0)=23.108$ and growth factor $k=1.612739878 \times 10^{-6}$.

\footnotetext{
${ }^{1}$ This can be done using software packages such as GeoGebra (geogebra.org).
} 
Table 2

Overview of each country's $\mathrm{CO}_{2}$ emissions of the passenger vehicle fleet in 2018 vs. 2035.

\begin{tabular}{|c|c|c|c|c|c|c|c|c|c|c|c|c|c|c|c|c|}
\hline Country & $\begin{array}{l}\text { Avg. } \\
\text { annual } \\
\text { km } \\
\text { travelled }\end{array}$ & $\begin{array}{l}\text { ICE fuel } \\
\text { consump-tion } \\
\text { per } 100 \mathrm{~km} \\
(\text { lge })^{1)}\end{array}$ & $\begin{array}{l}\mathrm{ICE} \mathrm{CO}_{2} \\
\text { emission } \\
\text { per } 1 \mathrm{~km} \\
(\mathrm{~kg})^{1)}\end{array}$ & $\begin{array}{l}\mathrm{CO}_{2} \text { emission } \\
\text { per } 1 \mathrm{kWh} \\
\text { electricity } \\
\left(\mathrm{kg}^{2)}\right.\end{array}$ & $\begin{array}{l}\text { EV } \\
\text { Inventory } \\
2018 \\
\text { (million) }\end{array}$ & $\begin{array}{l}\text { ICE } \\
\text { Inventory } \\
2018 \\
\text { (million) }\end{array}$ & $\begin{array}{l}\text { Total } \\
\text { Inventory } \\
2018 \\
\text { (million) }\end{array}$ & $\begin{array}{l}\text { EV } \\
\text { Inventory } \\
2035 \\
\text { (million) }\end{array}$ & $\begin{array}{l}\text { ICE } \\
\text { Inventory } \\
2035 \\
\text { (million) }\end{array}$ & $\begin{array}{l}\text { Total } \\
\text { Inventory } \\
2035 \\
\text { (million) }\end{array}$ & $\begin{array}{l}\text { Year when } \\
50 \% \text { EVs } \\
\text { are } \\
\text { reached }\end{array}$ & $\begin{array}{l}\text { Total } \mathrm{CO}_{2} \\
2018 \\
\text { (million } \\
\text { tons) }\end{array}$ & $\begin{array}{l}\text { Total } \mathrm{CO}_{2} \\
2035 \\
\text { (million } \\
\text { tons) }\end{array}$ & $\begin{array}{l}\text { Change in } \mathrm{CO}_{2} \\
\text { emission } \\
2018-2035 \\
\text { (\%) }\end{array}$ & $\begin{array}{l}\text { Total } \mathrm{CO}_{2} 2035 \\
\text { for ICEs only } \\
\text { (million tons) }\end{array}$ & $\begin{array}{l}\mathrm{CO}_{2} \text { emission } \\
2035 \text { compared } \\
\text { to ICEs only (\%) }\end{array}$ \\
\hline Australia & $13,301^{3)}$ & 7.9 & 0.188 & 0.798 & 0.012 & 14.2 & 14.2 & 6.9 & 10.4 & 17.3 & $>2035$ & 35.6 & 39.5 & $10.9 \%$ & 43.2 & $-8.6 \%$ \\
\hline Austria & $14,311^{4)}$ & 5.7 & 0.136 & 0.166 & 0.030 & 4.9 & 4.9 & 3.4 & 2.2 & 5.6 & 2033 & 9.6 & 5.8 & $-39.3 \%$ & 11.0 & $-47.1 \%$ \\
\hline Belgium & $14,500^{5)}$ & 5.6 & 0.133 & 0.199 & 0.047 & 5.8 & 5.8 & 5.5 & 1.1 & 6.6 & 2030 & 11.1 & 5.1 & $-54.2 \%$ & 12.7 & $-59.9 \%$ \\
\hline Brazil & $20,000^{6)}$ & 7.6 & 0.179 & 0.134 & 0.001 & 37.4 & 37.4 & 7.1 & 40.7 & 47.8 & $>2035$ & 133.7 & 149.1 & $11.5 \%$ & 171.1 & $-12.8 \%$ \\
\hline Canada & $15,200^{7)}$ & 8.9 & 0.206 & 0.158 & 0.090 & 22.6 & 22.7 & 7.9 & 16.5 & 24.4 & $>2035$ & 70.7 & 55.2 & $-21.8 \%$ & 76.5 & $-27.8 \%$ \\
\hline China & $18,778^{8)}$ & 7.6 & 0.175 & 0.711 & 2.466 & 196.0 & 198.4 & 177.8 & 171.5 & 349.3 & 2035 & 650.0 & 1002.6 & $54.2 \%$ & 1147.7 & $-12.6 \%$ \\
\hline Denmark & $14,000^{9)}$ & 5.2 & 0.124 & 0.300 & 0.015 & 2.5 & 2.5 & 2.0 & 0.9 & 2.9 & 2033 & 4.4 & 3.1 & $-28.6 \%$ & 5.1 & $-38.4 \%$ \\
\hline Finland & $17,611^{10)}$ & 5.8 & 0.135 & 0.175 & 0.012 & 2.6 & 2.6 & 1.8 & 1.0 & 2.8 & 2033 & 6.3 & 3.5 & $-45.0 \%$ & 6.7 & $-48.3 \%$ \\
\hline France & $12,977^{11)}$ & 5.3 & 0.126 & 0.064 & 0.205 & 32.4 & 32.6 & 19.7 & 14.2 & 33.9 & 2034 & 53.0 & 26.3 & $-50.5 \%$ & 55.4 & $-52.6 \%$ \\
\hline Germany & $14,107^{12)}$ & 5.9 & 0.140 & 0.486 & 0.211 & 46.4 & 46.6 & 34.6 & 17.6 & 52.2 & 2032 & 91.9 & 78.6 & $-14.5 \%$ & 103.0 & $-23.7 \%$ \\
\hline Hong Kong & $18,060^{13)}$ & 7.8 & 0.180 & 0.975 & 0.010 & 0.6 & 0.6 & 0.5 & 0.2 & 0.8 & 2033 & 1.9 & 2.5 & $29.0 \%$ & 2.5 & $0.1 \%$ \\
\hline India & $20,800^{14)}$ & 5.6 & 0.135 & 0.791 & 0.006 & 27.3 & 27.3 & 2.3 & 60.1 & 62.4 & $>2035$ & 76.6 & 175.7 & $129.5 \%$ & 175.2 & $0.3 \%$ \\
\hline Italy & $9,596^{15)}$ & 5.2 & 0.124 & 0.343 & 0.028 & 37.9 & 37.9 & 15.8 & 24.4 & 40.2 & $>2035$ & 45.1 & 38.6 & $-14.4 \%$ & 47.8 & $-19.2 \%$ \\
\hline Japan & $9,228^{16)}$ & 6.2 & 0.144 & 0.572 & 0.261 & 62.0 & 62.3 & 17.0 & 51.1 & 68.1 & $>2035$ & 82.7 & 84.5 & $2.2 \%$ & 90.5 & $-6.6 \%$ \\
\hline Netherlands & $13,022^{18)}$ & 5.4 & 0.127 & 0.452 & 0.149 & 8.5 & 8.6 & 5.3 & 4.3 & 9.7 & 2034 & 14.2 & 13.0 & $-8.6 \%$ & 16.0 & $-18.8 \%$ \\
\hline Norway & $12,140^{19)}$ & 5.1 & 0.121 & 0.008 & 0.254 & 2.4 & 2.6 & 2.5 & 0.4 & 2.9 & 2026 & 3.5 & 0.7 & $-80.2 \%$ & 4.2 & $-83.5 \%$ \\
\hline Portugal & $21,606^{20)}$ & 5.0 & 0.119 & 0.281 & 0.017 & 4.7 & 4.7 & 3.0 & 2.2 & 5.2 & 2034 & 12.1 & 9.0 & $-25.8 \%$ & 13.3 & $-32.7 \%$ \\
\hline Russia & $17,500^{21)}$ & 8.2 & 0.192 & 0.439 & 0.002 & 46.4 & 46.4 & 14.7 & 39.0 & 53.7 & $>2035$ & 155.8 & 152.0 & $-2.4 \%$ & 180.5 & $-15.8 \%$ \\
\hline South Africa & $25,000^{22)}$ & 7.4 & 0.176 & 0.926 & 0.001 & 6.8 & 6.8 & 0.3 & 8.4 & 8.7 & $>2035$ & 30.0 & 38.2 & $27.3 \%$ & 38.3 & $-0.1 \%$ \\
\hline South Korea & $12,184^{17)}$ & 6.3 & 0.147 & 0.536 & 0.060 & 18.2 & 18.2 & 4.6 & 21.2 & 25.7 & $>2035$ & 32.6 & 43.5 & $33.3 \%$ & 46.1 & $-5.8 \%$ \\
\hline Spain & $12,535^{23)}$ & 5.4 & 0.130 & 0.247 & 0.035 & 23.1 & 23.1 & 12.5 & 14.0 & 26.6 & $>2035$ & 37.6 & 30.1 & $-20.2 \%$ & 43.3 & $-30.6 \%$ \\
\hline Sweden & $12,240^{24)}$ & 5.9 & 0.139 & 0.013 & 0.081 & 4.8 & 4.9 & 4.5 & 0.9 & 5.4 & 2029 & 8.2 & 1.7 & $-79.1 \%$ & 9.2 & $-81.5 \%$ \\
\hline Switzerland & $13,469^{25)}$ & 6.4 & 0.152 & 0.024 & 0.036 & 4.7 & 4.7 & 3.2 & 1.7 & 4.9 & 2033 & 9.5 & 3.7 & $-61.2 \%$ & 10.1 & $-63.4 \%$ \\
\hline Taiwan & $16,167^{26)}$ & 7.3 & 0.170 & 0.906 & 0.001 & 6.8 & 6.8 & 0.1 & 7.4 & 7.6 & $>2035$ & 18.6 & 20.8 & $11.6 \%$ & 20.8 & $0.0 \%$ \\
\hline UK & $13,177^{27)}$ & 5.8 & 0.137 & 0.459 & 0.203 & 34.5 & 34.7 & 24.3 & 14.1 & 38.4 & 2033 & 62.5 & 52.6 & $-15.8 \%$ & 69.2 & $-24.1 \%$ \\
\hline USA & $21,682^{28)}$ & 8.6 & 0.198 & 0.489 & 1.126 & 123.9 & 125.0 & 62.0 & 68.0 & 130.0 & $>2035$ & 534.0 & 413.6 & $-22.5 \%$ & 558.1 & $-25.9 \%$ \\
\hline Total & 16,980 & 7.1 & 0.165 & 0.584 & 5.357 & 777.1 & 782.4 & 439.2 & 593.7 & 1032.9 & $>2035$ & 2191.2 & 2449.0 & $11.8 \%$ & 2957.4 & $-17.2 \%$ \\
\hline
\end{tabular}

Note lge $=$ liters gasoline equivalent. References 1 ) and 2) are listed in Appendix D. 


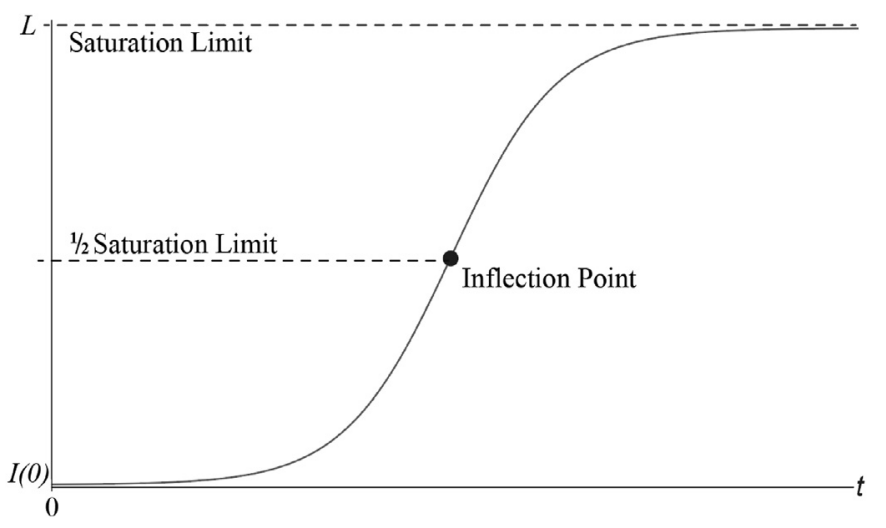

Fig. 1. Logistic growth function.

\section{Results}

Applying the above-described procedure to all 26 countries resulted in the numbers reported in Appendix B. Across all countries, in 2018, 2.1 million EVs were sold with a total end-of-year inventory of 5.4 million. By 2035, an inventory of 440 million EVs is expected, which then represents $42.5 \%$ of the total car inventory. Globally, 30\% of all passenger vehicles will be EVs in 2032.

Sensitivity analyses supported the results' robustness and showed that the curve continuously shifted to the right each year (see Appendix C). Specifically, the inflection point moved to the right from function (1) to (2) by 17 months, from (2) to (3) by 11 months, and from (3) to (4) by 4 months. Similarly, the point when a total inventory of 300 million EVs will be reached moves to the right. Hence, the more data points from previous years are available, the more stable the

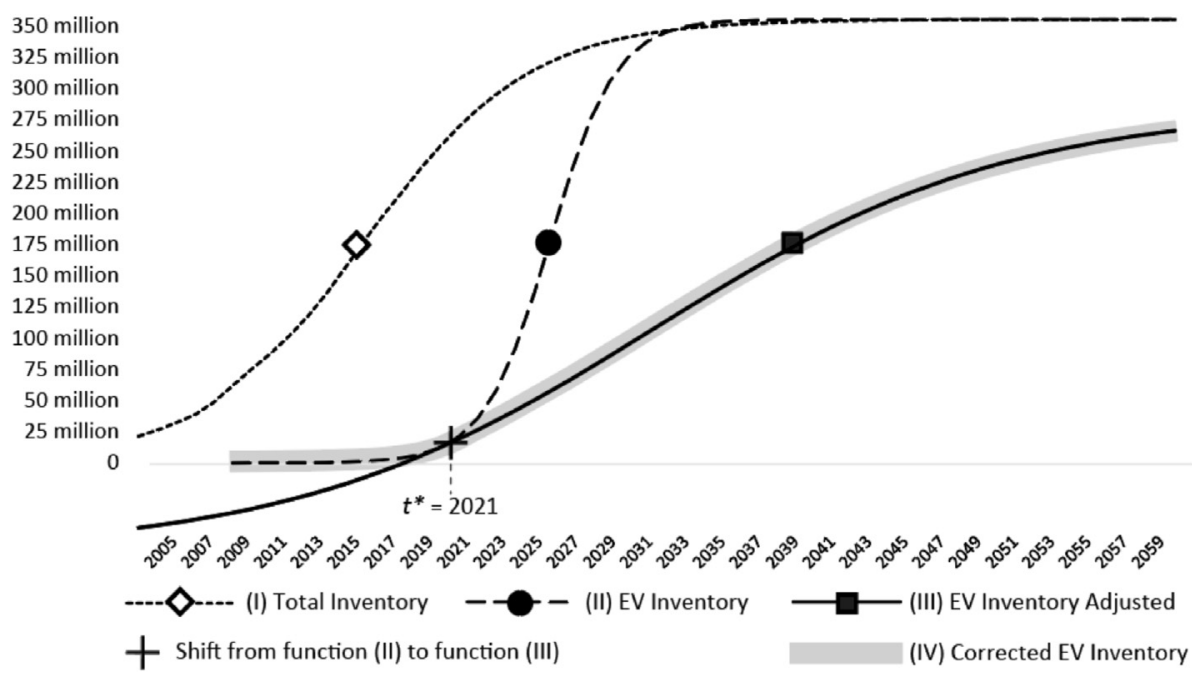

Fig. 2. Actual inventories (2005-2018) and forecasts in China ( $L=355$ million).

$$
I_{I I}(t)=\frac{355,000}{1+\left(\frac{355,000}{23.108}-1\right) \cdot e^{-1.612739878 \times 10^{-6} \cdot 355,000 \cdot t}}
$$

(Note: $L$ and $I(0)$ are denoted in 1000 units).

Applying (2) with $t=0$ for the year 2010 to estimate sales from 2019 onward (Function II, i.e. (II) EV Inventory, Fig. 2) predicts EV sales of 33.5 million in 2025. This is much higher than the maximum number of total passenger cars sold so far in China (2017: 24.7 million, 2018: 23.7 million, 2019: predicted 21.3 million; Statista, 2019). An upper limit of 22 million total annual car sales can be expected in China and EV sales should be below this number. The slope of the EV inventory function (II) was replaced accordingly by a flatter function from 2021 onwards, when both functions have the same predicted inventory and the same growth rate $\left(\right.$ at $\left.t=t^{*}\right){ }^{2}$ Appendix A displays detailed calculations. The resulting EV inventory forecast is shown as function IV (grey shaded) in Fig. 2. Respective numbers (inventories, sales, EV market shares, sales growth) for China are shown in Appendix B. Fig. 3 further shows inventories and EV sales in China from $2010-2035 .^{3}$

\footnotetext{
${ }^{2}$ See Appendix A, Mathematica was used for calculations (http://www.wolfram. $\mathrm{com} / \mathrm{mathematica/).}$

${ }^{3}$ Note: To calculate the growth function, all years until the saturation point (in 2060 ) is reached have to be included. To reasonably predict inventories and sales the forecast was narrowed until 2035.
}

results.

Regarding sustainability implications, significant variations were found between countries (see Table 2). For the majority of countries, a reduction in $\mathrm{CO}_{2}$ emissions of the entire vehicle fleet is predicted. In some countries, however, the opposite or no significant change is expected.

\subsection{Results per country}

In order to highlight cross-national differences, the 26 countries were clustered into six groups, based on their EV penetration pace (fast $=50 \%$ penetration until 2035 vs. slow $=50 \%$ later than 2035) and change in $\mathrm{CO}_{2}$ emissions (high reduction, moderate reduction, nearly no reduction, increase, strong increase; each change considered relative within the sample). Each cluster will subsequently be discussed in more detail.

5.1.1. Fast EV penetration and high $\mathrm{CO}_{2}$ reduction (Norway, Sweden, Switzerland, Belgium, France, Finland)

A number of countries show strong $\mathrm{EV}$ growth and a high $\mathrm{CO}_{2}$ emission reduction. Norway displays a particularly high EV adoption, mainly due to policy measures that have been implemented since the 1990s (Figenbaum et al., 2015; Rietmann and Lieven, 2019). Moreover, Norway aims to have all new cars emission-free by 2025 (Milne, 2017) and to be carbon-neutral by 2050 (Figenbaum et al., 2015). The country's goal was to have 200,000 EVs on the roads by 2020 (van der Steen et al., 2015), which has already been exceeded in 2018 with an 


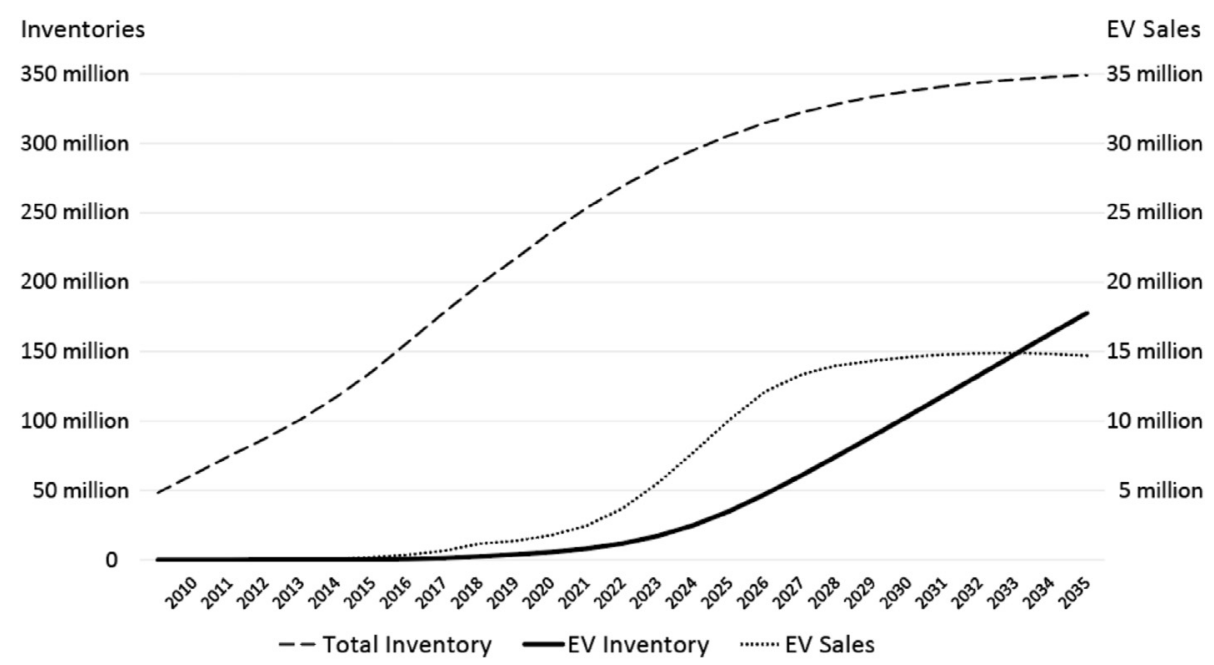

Fig. 3. Inventories and EV sales in China 2010-2035.

EV inventory of 254,000.

Furthermore, Norway produces $96 \%$ of energy using hydropower, resulting in only $8 \mathrm{~g} \mathrm{CO}_{2} / \mathrm{kWh}$ emissions (Energifakta Norge, 2019; OECD, 2019). Thus, the country will have reduced $\mathrm{CO}_{2}$ emissions by more than $80 \%$ until 2035 . Fig. 4 shows EV vs. ICE inventories from 2018 to 2035 and $\mathrm{CO}_{2}$ emissions, which are expected to drop significantly with the predicted EV growth. Other countries in this cluster (Sweden, Switzerland, Belgium, France, Finland) show similar results and improvements in $\mathrm{CO}_{2}$ reductions (see Table 2). This can particularly be attributed to the low emissions of their energy mixes, which all lie significantly below the OECD average of $432 \mathrm{~g} / \mathrm{kWh}$ (OECD, 2019). There are, however, some differences in the energy generation. While Norway, Sweden and Switzerland mostly rely on renewable sources (hydropower, wind energy), France and Belgium primarily use nuclear energy.

\subsubsection{Fast EV penetration and moderate $\mathrm{CO}_{2}$ reduction (Austria,} Denmark, Portugal, UK, Germany, Netherlands)

Another cluster displays fast EV penetration until 2035 but a comparatively low $\mathrm{CO}_{2}$ reduction (less than 50\%). Austria, for instance, has implemented various policy measures throughout the past years (EAFO, 2019). This is also the case in Denmark, Portugal, the UK, Germany, and the Netherlands. However, in all of these countries, the energy mixes result in higher $\mathrm{CO}_{2}$ emissions compared to the first country cluster (166-486 $\mathrm{g} \mathrm{CO}_{2} / \mathrm{kWh}$; OECD, 2019). Thus, emission reductions will not be as significant as in the first cluster if no improvements are made to the energy mixes.

\subsubsection{Slow EV penetration and moderate $\mathrm{CO}_{2}$ reduction (USA, Canada, Spain, Italy)}

The next cluster exhibits slower growth and is expected to reach a $50 \%$ EV penetration only after 2035 . Although policy measures have been implemented in all of these countries, they lack a sufficient charging infrastructure. For example, Spain only has 6 fast public charging points per $100 \mathrm{~km}$ highway, compared to 382 in Norway (EAFO, 2019). Nonetheless, the countries display low to moderate $\mathrm{CO}_{2}$ emissions from their electricity generation (about 20\% reduction until 2035), thereby leading to an overall moderate reduction in emissions over time. For example, $82 \%$ of Canada's energy mix consists of nonGHG emitting sources (Government of Canada, 2019). Hence, there is a lot of potential in these countries to improve sustainability with further EV growth.

\subsubsection{Slow EV penetration and nearly no $\mathrm{CO}_{2}$ reduction (Russia, Japan)}

Russia and Japan have so far shown very low EV market shares with close to $0 \%$ and $0.4 \%$ in 2018 , respectively (Appendix B).Japan has only recently implemented monetary incentives to support EV adoption (IEA IA-HEV, 2018) and Russia still lacks significant governmental support. Both countries rely heavily on fossil fuels to generate energy (Energy Information Administration, 2017; Ministry of Economy Trade and Industry, 2017). In order for sustainability improvements of EV growth to show in the long-term, the countries' energy mixes therefore need to be improved, and political incentives be strengthened.

\subsubsection{Slow EV penetration and $\mathrm{CO}_{2}$ increase (Australia, Brazil, Taiwan, South Africa, Hong Kong, korea)}

Another cluster shows rather low EV growth and $\mathrm{CO}_{2}$ increases over time. Reasons for this vary. Australia, South Africa, Korea and Hong Kong use very few renewable energy sources. For example, in Hong Kong $53 \%$ of the energy is produced from coal and only $2 \%$ from renewable sources (Government of Hong Kong, 2015). Other countries, such as Brazil, have installed large hydropower plants that account for approximately $80 \%$ of the domestic electricity generation (IEA, 2019b). Hence, there is potential to reduce $\mathrm{CO}_{2}$ emissions with a large-scale EV adoption over time. However, as the traditional automotive industry is very large in Brazil (OICA, 2019), the government shows very little interest in supporting EVs(Domingues and PecorelliPeres, 2013). Each country in this cluster must therefore tackle different issues to raise EV adoption sustainably.

\subsubsection{Slow EV penetration and strong $\mathrm{CO}_{2}$ increase (China, India)}

Finally, China and India currently show the highest hurdles in terms of long-term, sustainable EV adoption. The Indian government has provided comparatively low, and mostly local, support for EVs (Government of NCT of Delhi, 2016). China has also implemented a subsidy scheme in 2009 and further incentives since then (Hao et al., 2014; Zhu et al., 2017). In 2019, however, China has reduced EV incentives dramatically, leading to a sales drop (Toh, 2019). While EV sales increased by $50 \%$ annually from January to June 2019, it declined by $25 \%$ between July and October 2019 . In this study, numbers have been adjusted accordingly to a reasonable scenario, in which sales rise (maximum 50\% annual growth), however, not as strongly as previously (80\%).

Nonetheless, even if EV sales were supported more strongly in these countries, further growth with the current electricity mixes 


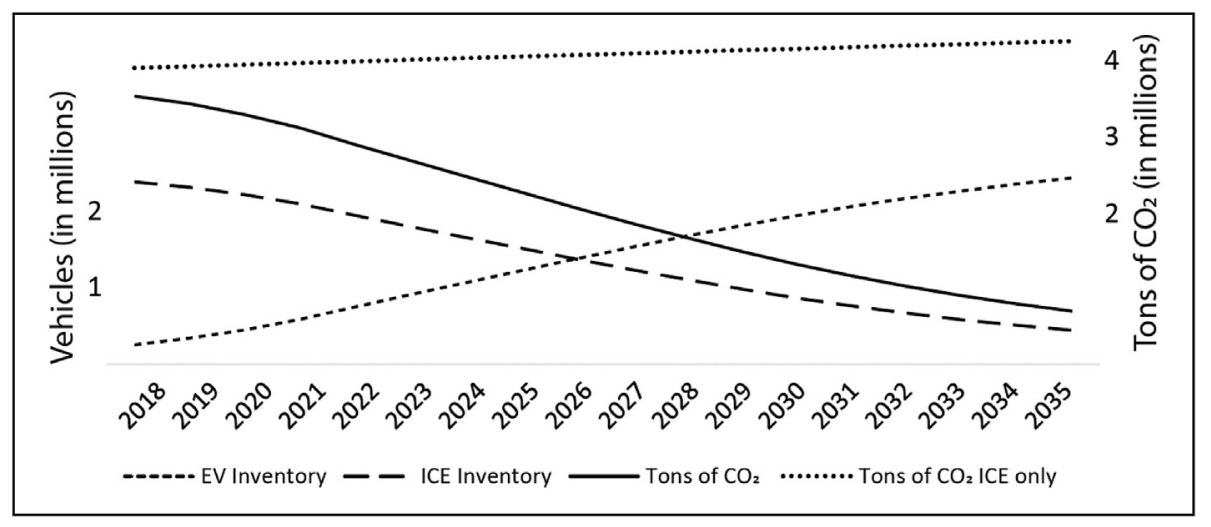

Fig. 4. $\mathrm{EV}$ vs. ICE inventories and $\mathrm{CO}_{2}$ emissions in Norway (in millions).

would be unsustainable. Coal accounts for $70-80 \%$ of the energy generation in China (Wu et al., 2018) and 56\% in India (BP, 2019). While China will reach a 50\% EV share of the car inventory in 2035, $\mathrm{CO}_{2}$ emissions will grow by $54.2 \%$. Compared to an ICE-only inventory in 2035 , the $\mathrm{EV}$ growth is still favorable though $\left(-12.6 \% \mathrm{CO}_{2}\right.$ emissions). Countries such as China and India should therefore simultaneously raise EV sales and switch to more renewable energy sources. Although Norway and China are difficult to compare because of their size, Figs. 4 and 5 represent the extreme opposites in sustainability development among all countries.

Fig. 6 finally summarizes results for all 26 countries. Although the EV inventory reaches $42.5 \%$ in $2035, \mathrm{CO}_{2}$ emissions rise by $11.8 \%$ between 2018 and 2035. A peak is reached in 2028, after which emissions gradually decrease. Compared to an ICE-only fleet, however, the $\mathrm{CO}_{2}$ reduction is significant $(-17.2 \%$ by 2035$)$.

\subsection{Implications for electricity and battery production}

The predicted EV growth will boost electricity demand in the coming years. In 2020, about 3.5 million EVs are expected to be sold in the 26 countries examined here. This figure is predicted to be about 20 million in 2025 and 42 million in 2035. Assuming that each $\mathrm{EV}$ is equipped with a 70-kWh battery for a range of about $300-400 \mathrm{~km}$, this would require the production of a total battery capacity of 2.94 Terawatt hours (TWh) in 2035. Even with the largest existing battery giga-factory, about $1 \%$ of this is produced today (35 GWh) and 5\% (150 GWh) are planned to be produced annually in the coming years (Techcrunch, 2019).

Furthermore, a vehicle's annual mileage must be considered which is approximately $17,000 \mathrm{~km}$ (Table 2). Electricity consumption per $\mathrm{km}$ is about $185 \mathrm{Wh}$ (Electric Vehicle Database, 2019) which adds up to 1381 TWh in 2035 (assuming a total EV inventory of 439 million). For each country, this will be an average charging demand of $7 \%$ of today's total electricity production, as shown in Table 3. In this table, the electricity production in 2017/18 is compared to 2000 . While some countries have seen a strong increase in production, other countries produced more electricity in 2000 than today. However, the latter should be able to reach this level again, based on their former higher production rates. In other countries, raising electricity production may be more difficult (e.g. UK). Hence, they should tackle this issue now. Although grid problems such as the distribution to the last mile could pose new challenges in the future, most countries should be able to cope with the additional electricity demand caused by the EV growth.

The major bottleneck in the EV development seems to be the battery production. Besides the provision of sufficient production capacity in more giga-factories, availability of basic raw materials may become a crucial issue. Battery production is becoming a new industrial sector. Assuming that the cost for $1 \mathrm{kWh}$ declines from today's US\$200 to about US\$ 100 in 2030 (Union of Concerned Scientists, 2019), this would result in a total yearly revenue of US\$ 294 billion for this new industry in the 26 countries alone.

\section{Discussion and conclusion}

EV sales will increase significantly in the coming years. By 2035 , the EV market share is expected to reach $42.5 \%$ worldwide. This study importantly shows that $\mathrm{CO}_{2}$ emissions from the passenger car fleet across all 26 countries will still increase until 2035. Nonetheless, some countries will see significant $\mathrm{CO}_{2}$ reductions.

Norway and Sweden, for instance, will reach a 50\% market share prior to 2035, which can particularly be attributed to strong governmental support (Lieven, 2015; Rietmann and Lieven, 2019). Due to the nations' favorable energy mixes, $\mathrm{CO}_{2}$ emissions will fall drastically

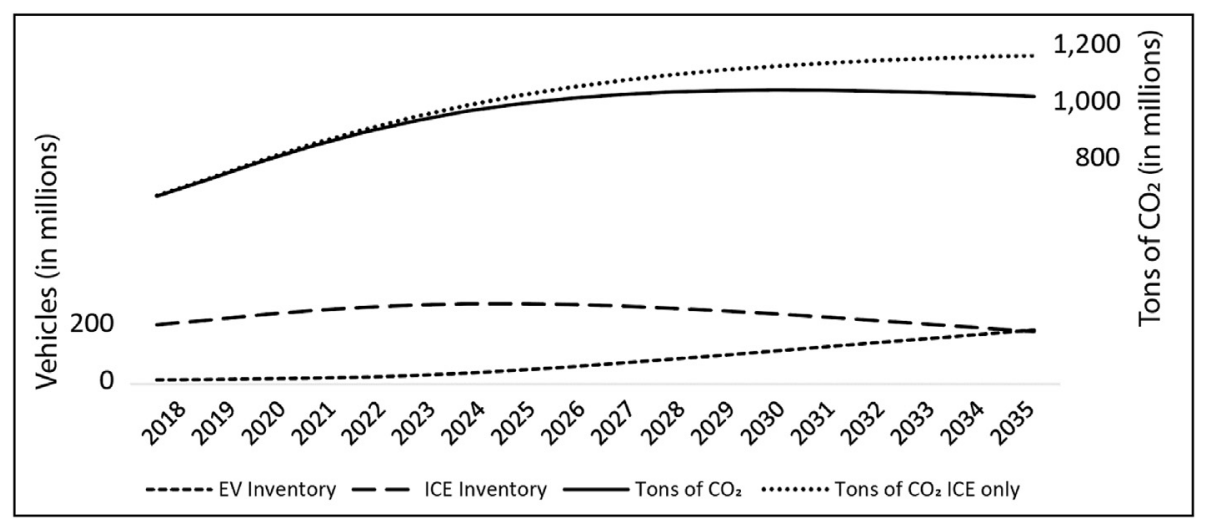

Fig. 5. EV vs. ICE inventories and $\mathrm{CO}_{2}$ emissions in China (in millions). 


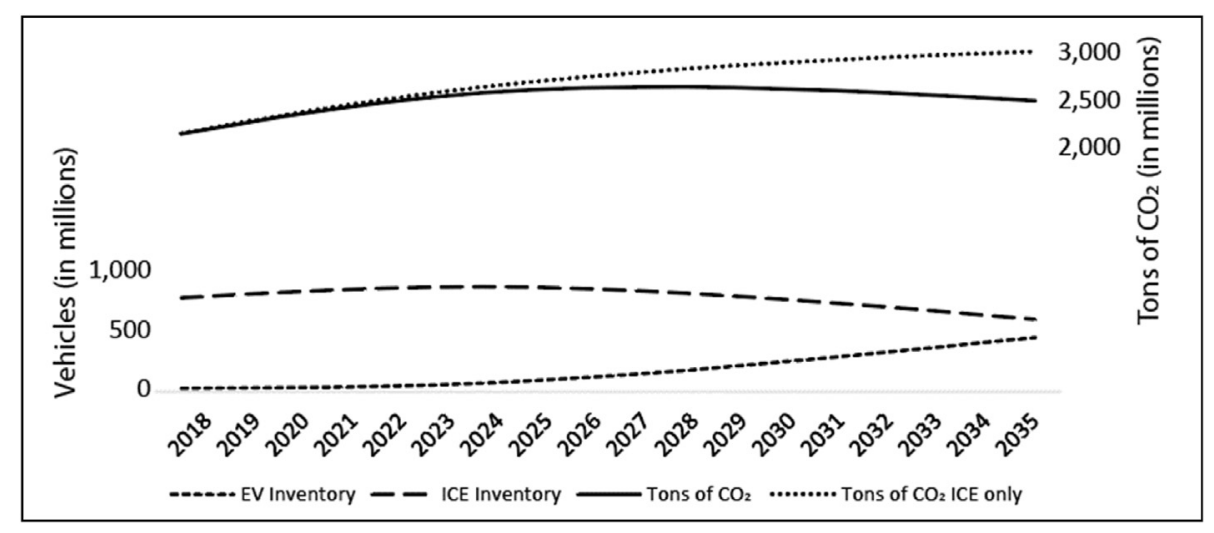

Fig. 6. EV vs. ICE inventories and $\mathrm{CO}_{2}$ emissions in all 26 countries (in millions).

Table 3

Electricity production and charging demand.

\begin{tabular}{|c|c|c|c|c|c|}
\hline Country & $\begin{array}{l}\text { Electricity production in } 2000 \\
\text { (TWh) }\end{array}$ & $\begin{array}{l}\text { Electricity production in } 2017 / 18 \\
\text { (TWh) }\end{array}$ & $\begin{array}{l}\text { Total inventory EVs in } 2035 \text { (in } \\
1000 \text { ) }\end{array}$ & $\begin{array}{l}\text { Charging demand in } 2035 \\
\text { (TWh) }\end{array}$ & $\begin{array}{l}\% \text { from total production in } \\
2017 / 18\end{array}$ \\
\hline Australia & 210.2 & 261.1 & 6913 & 21.7 & $8.3 \%$ \\
\hline Austria & 61.3 & 68.6 & 3438 & 10.8 & $15.8 \%$ \\
\hline Belgium & 84.0 & 75.0 & 5457 & 17.2 & $22.9 \%$ \\
\hline Brazil & 348.9 & 601.4 & 7104 & 22.3 & $3.7 \%$ \\
\hline Canada & 605.7 & 650.8 & 7917 & 24.9 & $3.8 \%$ \\
\hline China & 1387.1 & 6671.9 & 177,776 & 559.1 & $8.4 \%$ \\
\hline Denmark & 36.1 & 30.0 & 2033 & 6.4 & $21.3 \%$ \\
\hline Finland & 70.0 & 70.0 & 1782 & 5.6 & $8.0 \%$ \\
\hline France & 540.0 & 580.7 & 19,670 & 61.9 & $10.7 \%$ \\
\hline Germany & 576.5 & 649.9 & 34,615 & 108.9 & $16.8 \%$ \\
\hline Hong Kong & 31.3 & 37.0 & 524 & 1.6 & $4.5 \%$ \\
\hline India & 569.7 & 1532.2 & 2302 & 7.2 & $0.5 \%$ \\
\hline Italy & 276.6 & 290.6 & 15,792 & 49.7 & $17.1 \%$ \\
\hline Japan & 1067.8 & 1025.8 & 17,031 & 53.6 & $5.2 \%$ \\
\hline Korea & 290.1 & 579.9 & 4557 & 14.3 & $2.5 \%$ \\
\hline Netherlands & 89.6 & 113.5 & 5333 & 16.8 & $14.8 \%$ \\
\hline Norway & 143.0 & 147.5 & 2400 & 7.5 & $5.1 \%$ \\
\hline Portugal & 43.8 & 59.8 & 3010 & 9.5 & $15.8 \%$ \\
\hline Russia & 877.8 & 1109.2 & 14,675 & 46.2 & $4.2 \%$ \\
\hline South Africa & 210.7 & 255.1 & 281 & 0.9 & $0.3 \%$ \\
\hline Spain & 224.5 & 273.8 & 12,510 & 39.3 & $14.4 \%$ \\
\hline Sweden & 145.3 & 159.3 & 4492 & 14.1 & $8.9 \%$ \\
\hline Switzerland & 67.5 & 69.2 & 3223 & 10.1 & $14.6 \%$ \\
\hline Taiwan & 238.3 & 270.3 & 125 & 0.4 & $0.1 \%$ \\
\hline UK & 377.1 & 333.9 & 24,276 & 76.3 & $22.9 \%$ \\
\hline USA & 4052.7 & 4434.9 & 61,970 & 194.9 & $4.4 \%$ \\
\hline Total & $12,625.4$ & $20,351.7$ & 439,206 & 1381.3 & $6.8 \%$ \\
\hline
\end{tabular}

Source (Dudley, 2019; IEA, 2019c):

between 2018 and 2035 (-80\% in Norway). In other countries (e.g. South Africa, Brazil), EV adoption will be much slower. Moreover, benefits of a rising EV inventory crucially depend on a nation's energy mix. Countries such as China and India, which rely strongly on coal to generate energy, will not reap major benefits from introducing a largescale EV fleet with their current energy mixes, except that the EV fleet will lead to a less strong increase in $\mathrm{CO}_{2}$ emissions compared to an ICEonly fleet. The adoption of more renewable energy sources would have significant environmental advantages, as the example of Norway highlights. In some countries, however, the journey will be long. China, for instance, has implemented various laws and policies to establish more renewable energy sources but these have substantial issues such as fragmentation and lack of operability (Liu, 2019).

Although the predicted EV market shares may seem surprisingly high, our predictions can be deemed thorough. Firstly, the forecast of

\footnotetext{
${ }^{4}$ The second derivative of the exponential function is always positive while it is positive for the logistic growth function at the beginning, equals zero at the inflection point and is negative at the end.
}

a logistic growth model can be considered conservative. Although an exponential model may also represent the current growth quite well (e.g., yearly sales growth of $40 \%$ ), it may overestimate growth rates at the end of the cycle. ${ }^{4}$ The logistic growth function fits much better because a saturation limit can be expected.

Secondly, our results can be described as rather conservative. As the estimated growth functions were too steep in most countries, they were flattened from a specific year onward when EV sales exceeded those that were currently seen. Consequently, this study's estimations are mostly corrected downwards and below predictions based on actual EV sales.

Moreover, there are some specialties in the reporting of EV sales that need mentioning. For example, in the USA, SUVs are summarized under the light truck group. In other countries, SUVs are reported under the passenger car category. As this study only considered passenger cars, the EV market share may have been overestimated in the USA. This only holds for total inventory shares though.

Regarding $\mathrm{CO}_{2}$ emissions, we did not compare the entire EV vs. ICE lifecycle but focused on the cars' use phase. Including all factors influencing emissions (e.g., combustion engine vs. battery 
production, transport of crude oil to refineries and gas stations, etc.) would have been far beyond this study's scope. We suggest that future research should investigate this more deeply based on our growth projections.

The most challenging limitation lies in the nature of the curvefitting of a logistic growth function based on existing data. The more data available, the better the predicted model. Sensitivity analyses showed that the growth curve shifted to the right each year. Consequently, further shifts may occur in the future, possibly causing a delay of the forecasted rapid growth by six months to an entire year. If the shift of four months annually occurs, the growth curves have to be shifted forward by one year in 2022. This, however, may be compensated to some extent by our conservative estimations.

Another crucial point is the estimation of saturation limits. In developed countries, this may not be problematic since this limit has almost been reached (130 million in the USA). In China or India, predicting this saturation is more difficult. Discussing this issue with market experts showed consensus that China will see about 250 cars per 1,000 population which may result in the expected 355 million passenger cars in the future. India, however, is nearly impossible to predict. The assumed saturation of 100 million may be underestimated. Sensitivity analyses show that this saturation limit will not have a strong effect in the next decade. Growth functions for a worldwide limit of 1200 and 800 million are nearly identical when the EV inventory reaches 300 million EVs (Appendix C). Hence, the difficulty of finding an appropriate saturation will only become important in later years.

Furthermore, there are some uncertainties that should be considered in future studies. For example, it is unclear whether all countries would be able to actually accommodate the estimated growth in passenger vehicles. Also, technological disruptions such as autonomous cars and trends toward carsharing may have significant implications on car sales in the future (Burns, 2013; Shaheen and Cohen, 2013). Moreover, this study assumed that carbon intensity of electricity generation and electricity consumption of EVs will be the same in 2035 as in 2018. Future research could further investigate an improvement of these factors and account for it in the calculation. Yet, EV outlook numbers from 2019 as predicted by the IEA indicate a certain level of validity for this study's data (OECD/IEA, 2019).

To conclude, this paper presents a long-term forecast of EV sales in 26 countries until 2035 . The logistic growth model, which was based on actual sales data from 2010 to 2018, predicts that 30\% of all passenger vehicles will be EVs in 2032. Furthermore, significant crossnational differences are established regarding sustainability implications. In order for the rising EV inventory to be sustainable, countries must invest in large-scale renewable energy sources. Future studies should continuously investigate market developments as various factors influence EV growth, such as changes in policy measures. At the same time, EV producers and energy providers should monitor these predictions over time and adapt their production plans accordingly. Finally, governments should consider this study's findings to plan investments and policies which both support EV growth as well as the development of more renewable energy mixes.

\section{Appendix A. Growth function calculations}

Given is a growth function

$$
I_{I I}(t)=\frac{L}{1+\left(\frac{L}{I_{I I}(0)}-1\right) \cdot e^{-k \cdot(L) \cdot t}}
$$

with $I_{I I}(t)=$ Inventory at time $t, L=$ Saturation Limit, $I_{I I}(0)=$ Inventory at the beginning $(t=0), k=$ growth factor.

Find a less steep growth function $I_{I I I}$ being tangent to $I_{I I}$ at a chosen point $t^{*}$ where function values and the respective derivatives are equal:

$$
I_{I I I}\left(t^{*}\right)=I_{I I}\left(t^{*}\right) \text { and } I_{I I I}^{\prime}\left(t^{*}\right)=I_{I I}^{\prime}\left(t^{*}\right)
$$

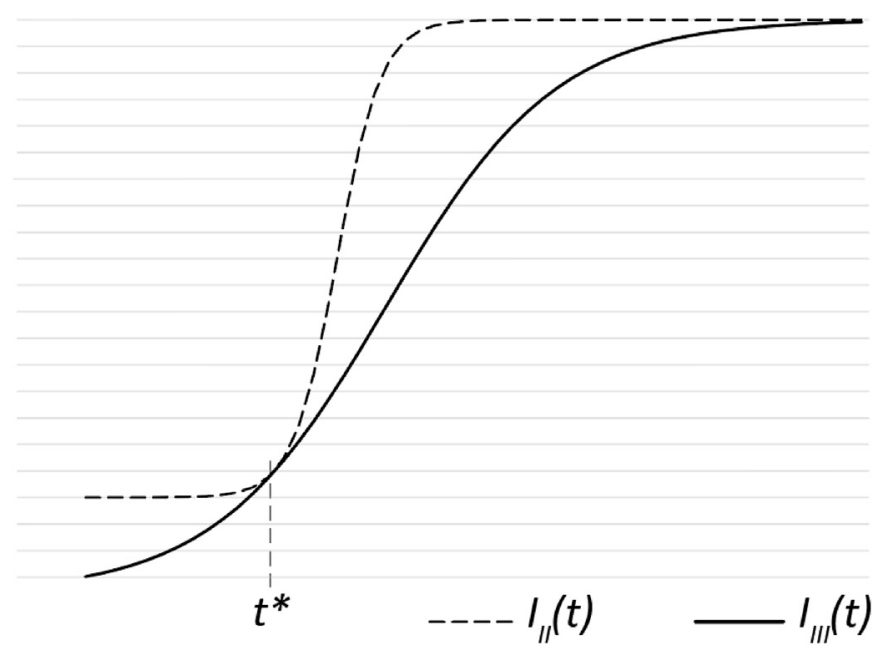

Fig. A1. Two tangential growth functions

Define the growth function $I_{I I I}$ with a higher saturation $\operatorname{limit} L+c$ and subtract $c$ from the function value. By this, $I_{I I I}$ will start below 0 at $t=0$, however, converge to the original saturation limit $L$.

$$
I_{I I I}(t)=\frac{L+c}{1+\left(\frac{L+c}{I_{I I I}(0)}-1\right) \cdot e^{-k \cdot(L+c) \cdot t}}-c
$$

Solve (A3) for $I_{I I I}(0)$ under the condition that $I_{I I I}\left(t^{*}\right)=I_{I I}\left(t^{*}\right)$ :

$$
I_{I I I}(0)=\frac{(L+c) \cdot\left(c+I_{I I}\left(t^{*}\right)\right)}{c+I_{I I}\left(t^{*}\right)-\mathrm{e}^{k(L+c) t} \cdot I_{I I}\left(t^{*}\right)+\mathrm{e}^{k(L+c) t} \cdot L}
$$

The derivative of $I_{I I I}$ is:

$I_{I I I}^{\prime}(t)=\frac{\mathrm{e}^{-k(L+c) t} k \cdot(L+c)^{2} \cdot\left(-1+\frac{L+c}{I_{I I I}(0)}\right)}{\left(1+\mathrm{e}^{-k(L+c) t} \cdot\left(-1+\frac{L+c}{I_{I I I}(0)}\right)\right)^{2}}$

Solve (A5) for $k$ under the condition that $I_{I I I}^{\prime}\left(t^{*}\right)=I_{I I}^{\prime}\left(t^{*}\right)$ :

$k=\frac{I_{I I}^{\prime}\left(t^{*}\right)}{\left(L-I_{I I}\left(t^{*}\right)\right) \cdot\left(c+I_{I I}\left(t^{*}\right)\right)}$

and insert $k$ in (A4) to find $I_{I I I}(0)$ :

$$
I_{I I I}(0)=\frac{(L+c) \cdot\left(c+I_{I I}\left(t^{*}\right)\right)}{c+I_{I I}\left(t^{*}\right)-\mathrm{e}^{\frac{I_{I I}\left(t^{*}\right) \cdot(L+c) \cdot I^{*}}{\left.\left(L-t^{*}\right)\right) \cdot\left(c+I_{I I}\left(t^{*}\right)\right)}} \cdot I_{I I}\left(t^{*}\right)+\mathrm{e}^{\frac{I_{I I}\left(t^{*}\right) \cdot(L+c) t^{*}}{\left(L-I_{I}\left(t^{*}\right)\right) \cdot\left(c+I_{I I}\left(t^{*}\right)\right)}} \cdot L}
$$

Appendix B. Total and EV inventories, EV market share, annual EV sales in thousand units, and annual EV sales growth rate 


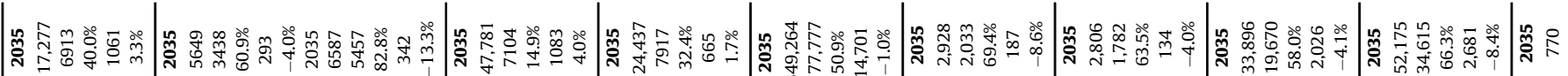

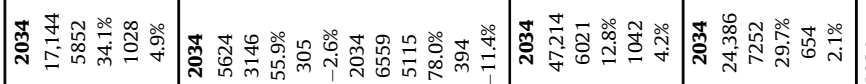

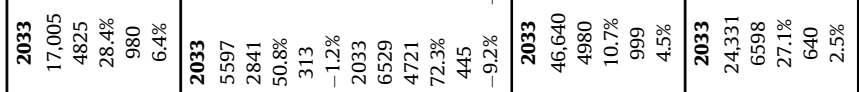

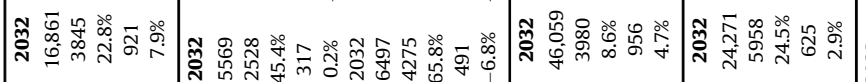

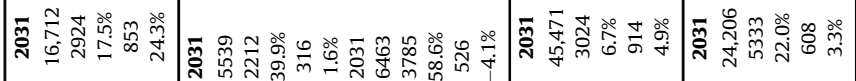

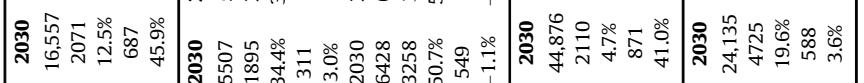

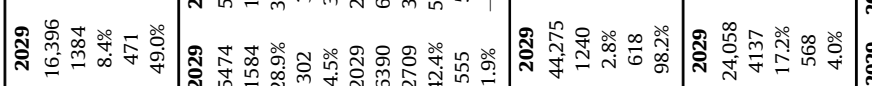

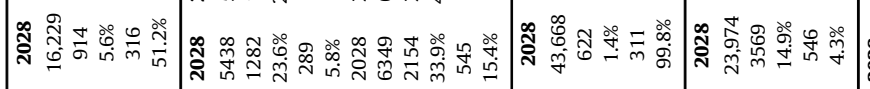

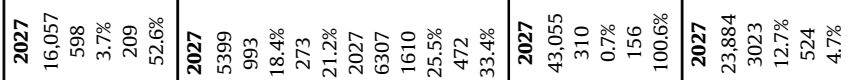

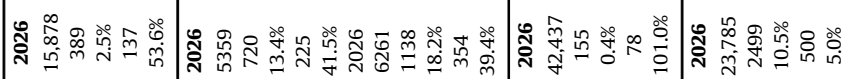

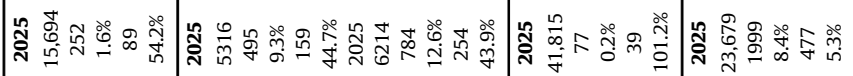

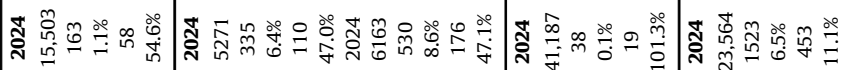

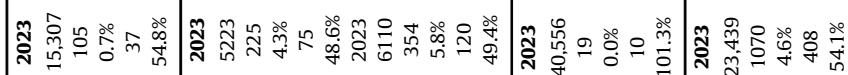

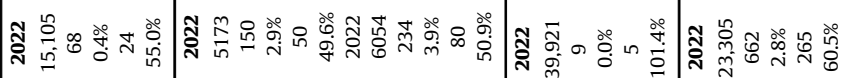

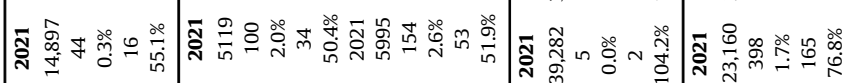

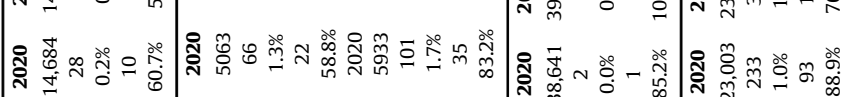

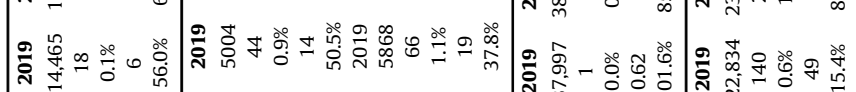

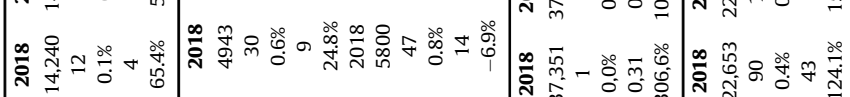

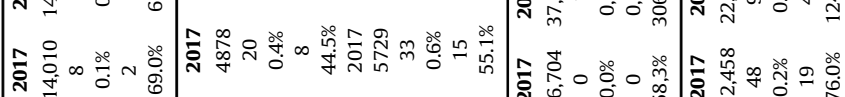

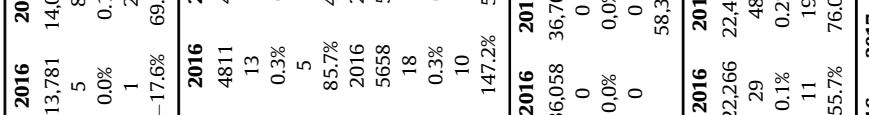

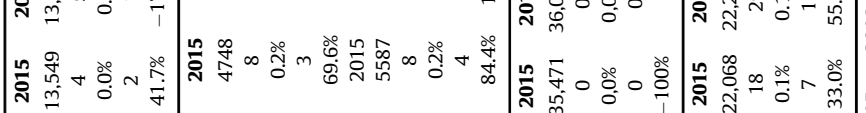

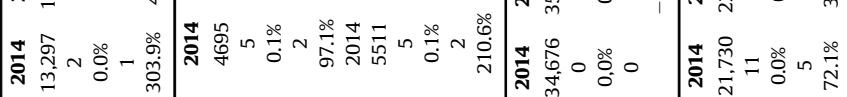

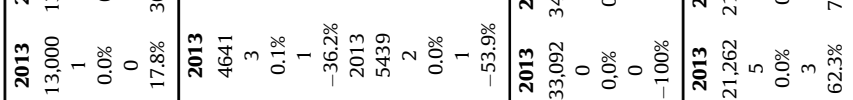

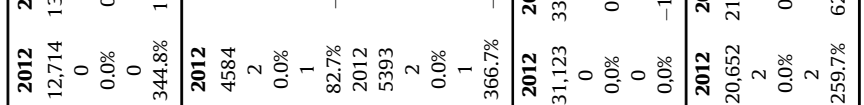

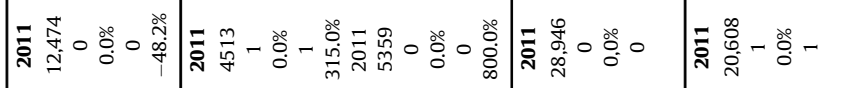

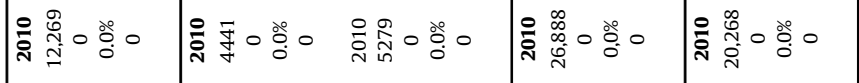

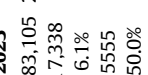

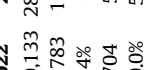

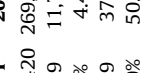

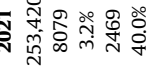

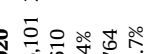

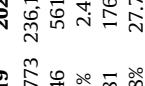

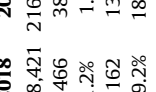

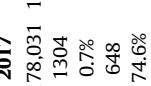

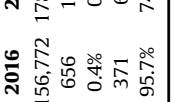

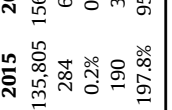

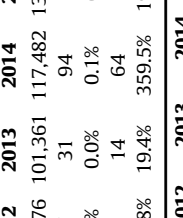

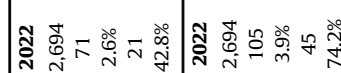

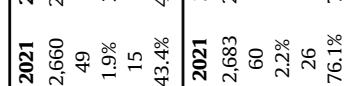

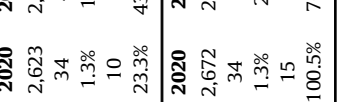

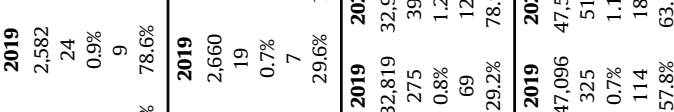

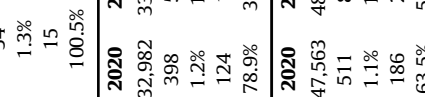

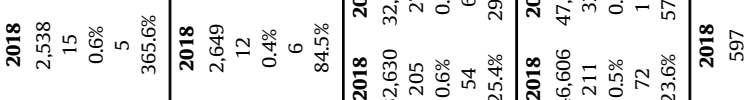

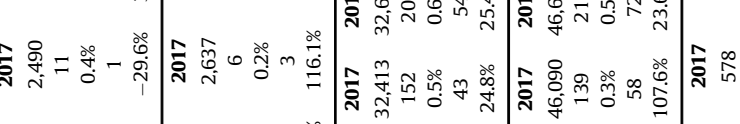

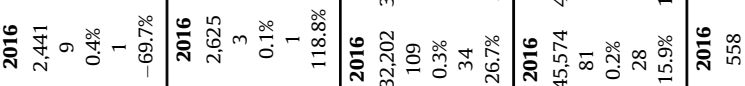

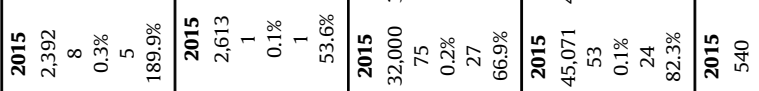

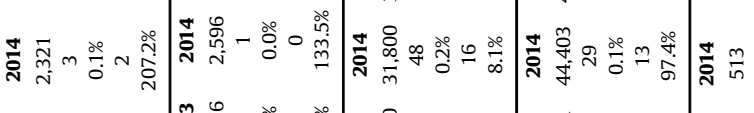

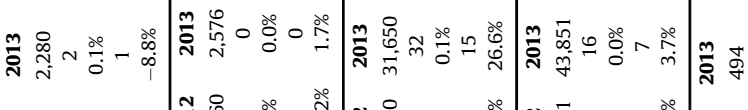

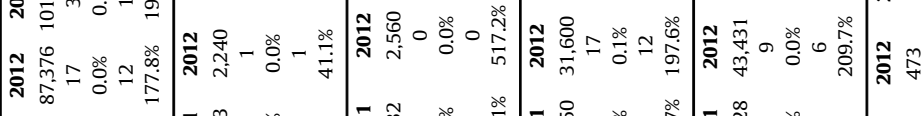

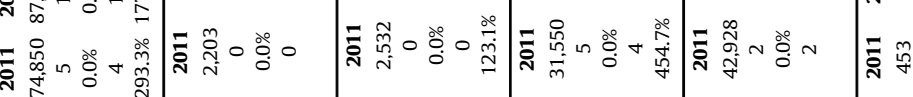

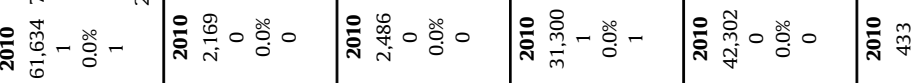

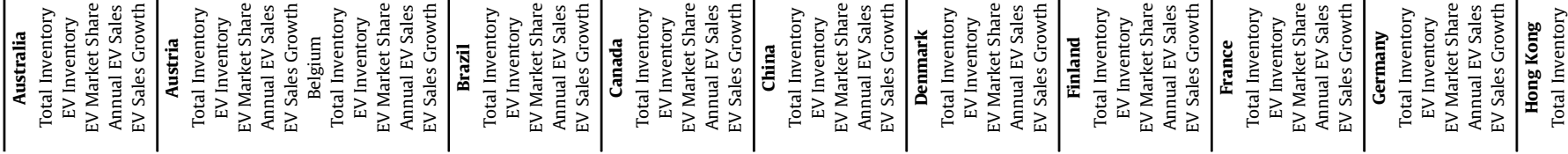




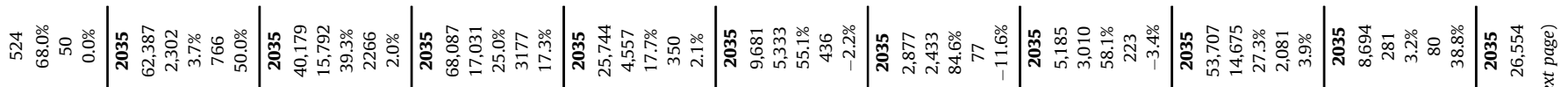

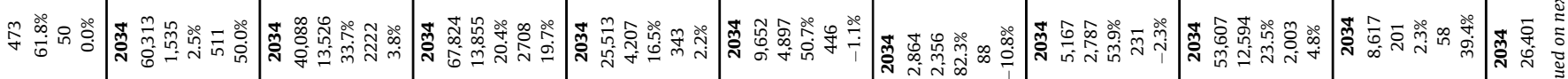

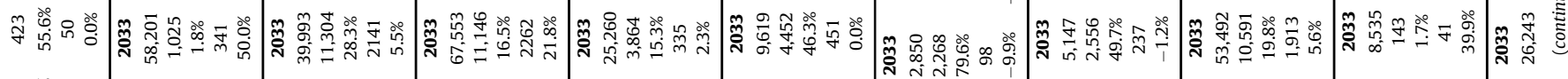

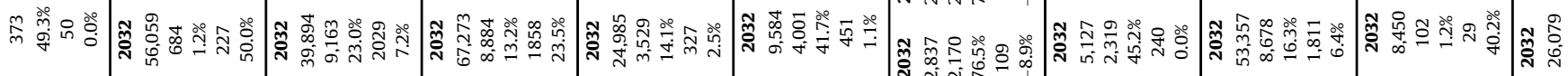

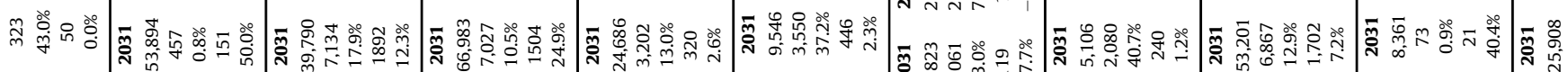

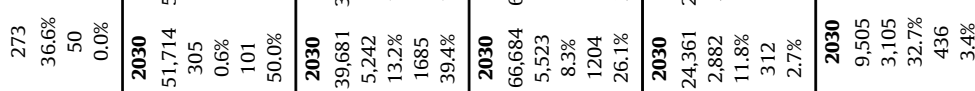

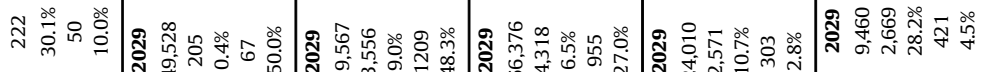

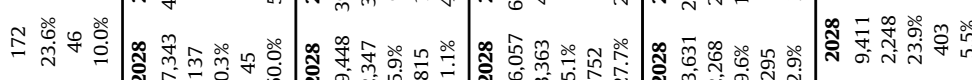

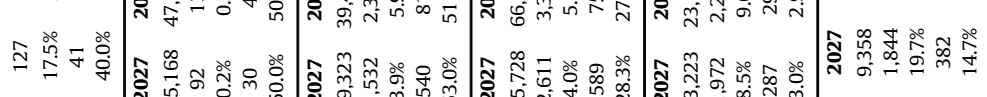

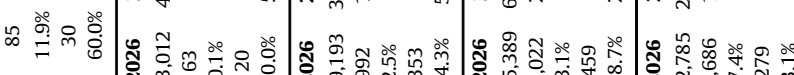

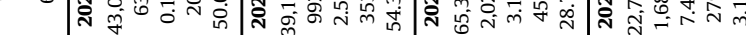

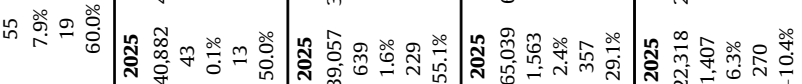

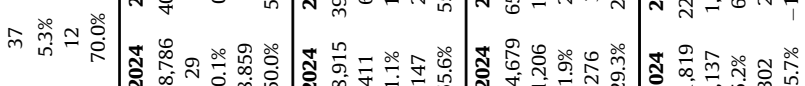

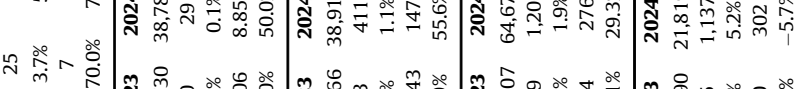

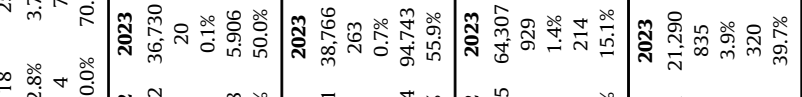

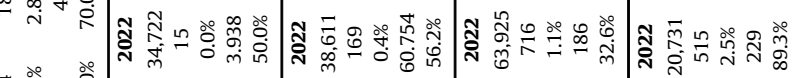

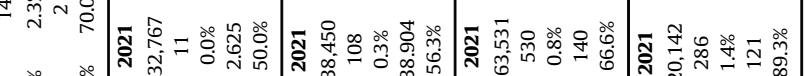

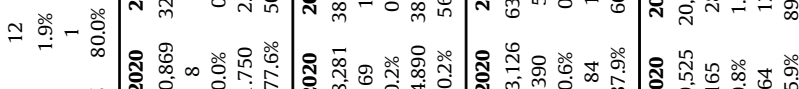

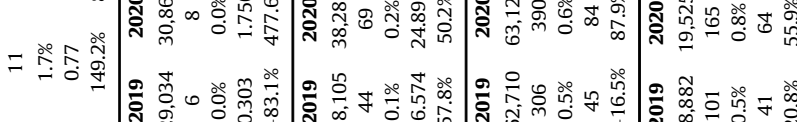

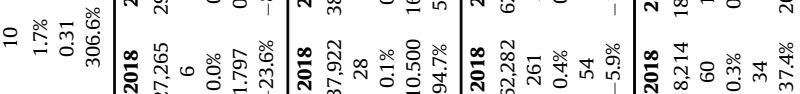

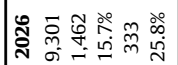

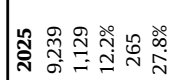

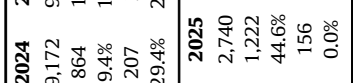

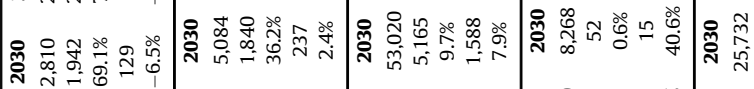

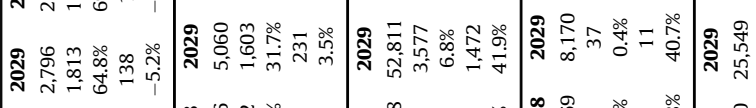

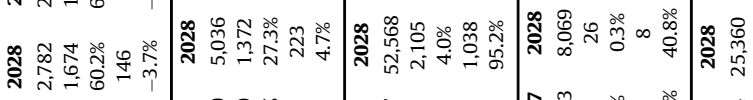

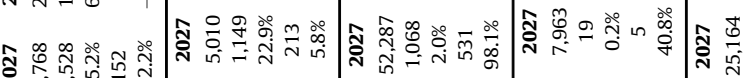

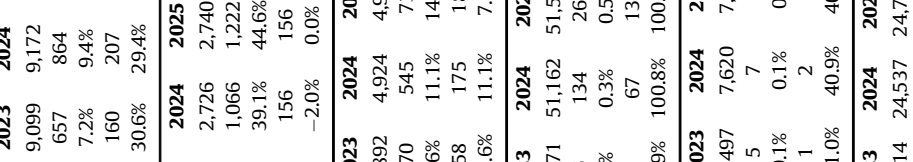

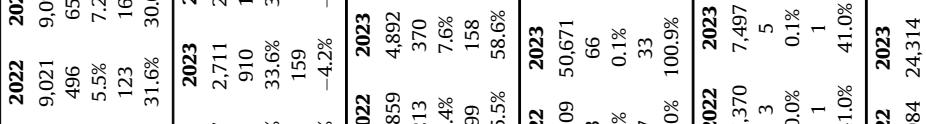

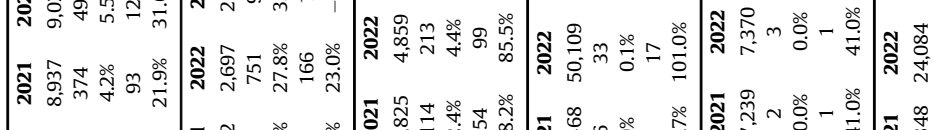

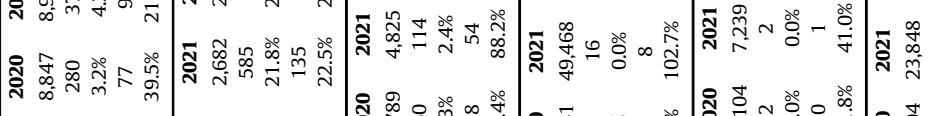

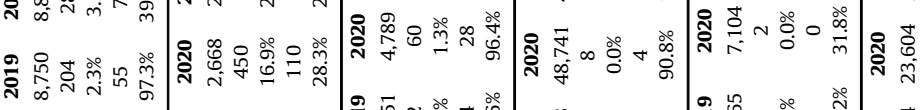

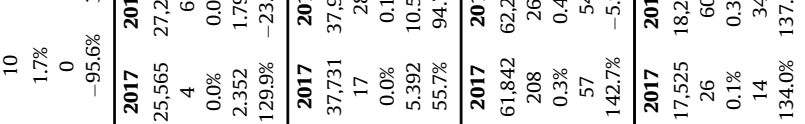

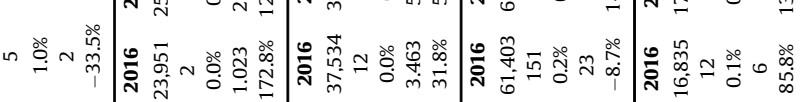

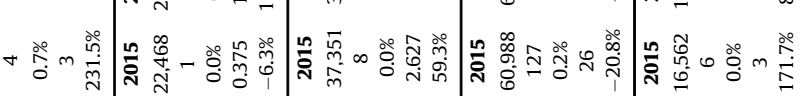

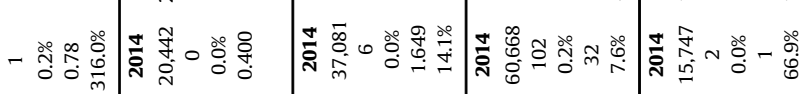

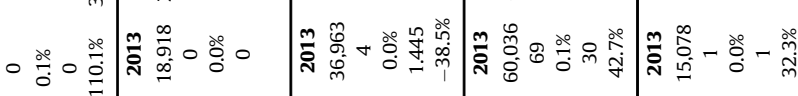

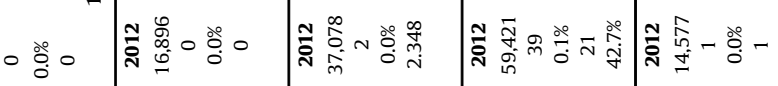

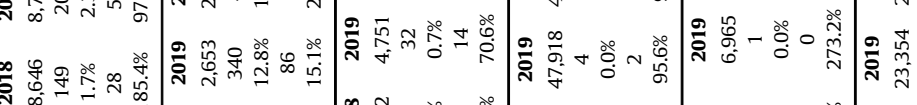

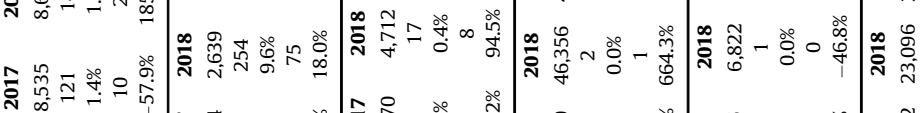

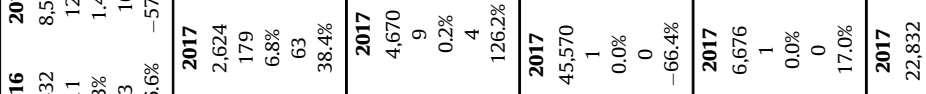

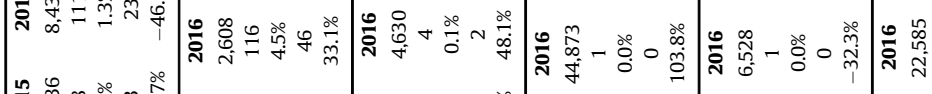

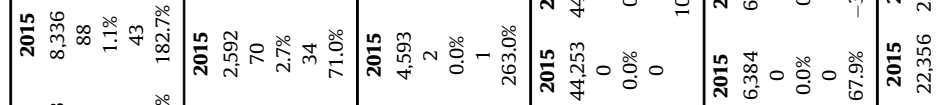

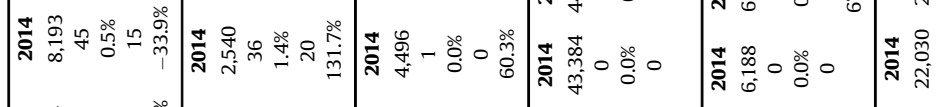

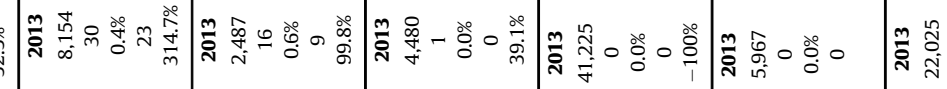

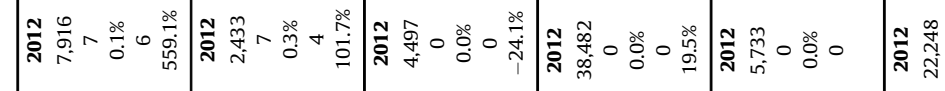

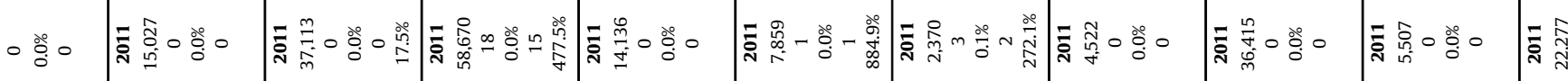

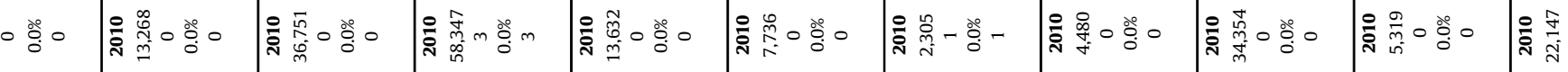

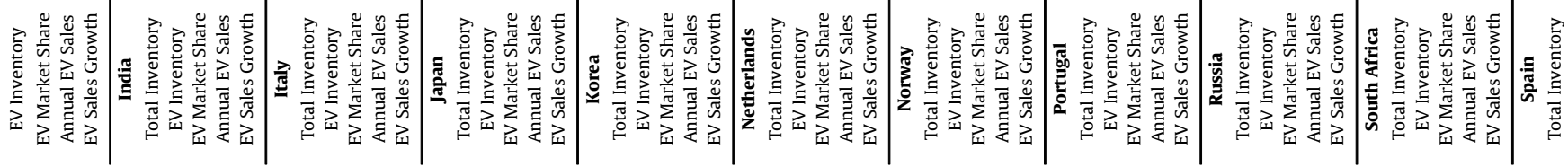




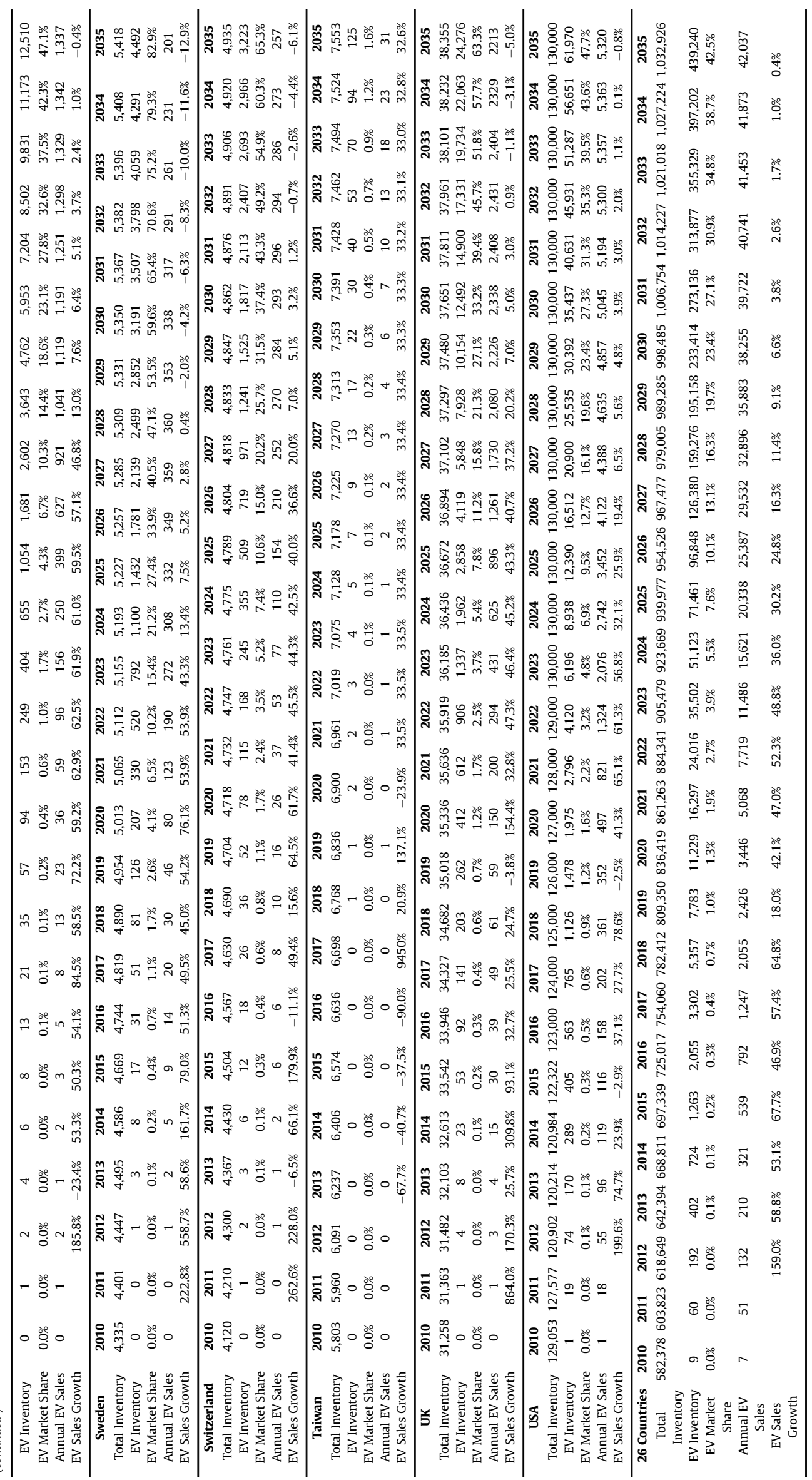


Appendix C. Sensitivity analyses regarding number of datapoints and saturation limit

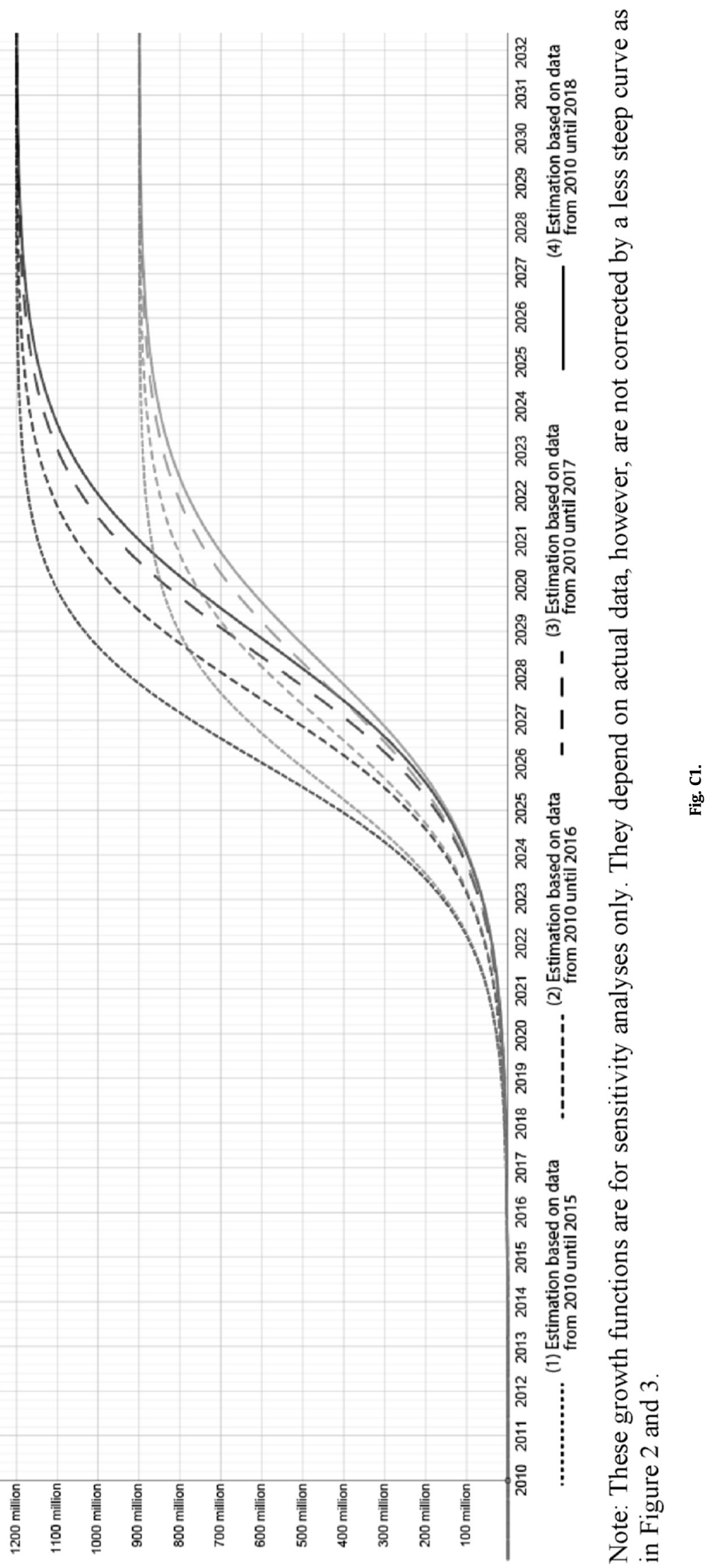


Table C1

Milestones for growth functions with saturation limit of 1200 million EVs

\begin{tabular}{|c|c|c|c|c|c|c|c|}
\hline & Growth function I & & Growth function II & & Growth function III & & Growth function IV \\
\hline Reaches inflection point & Jan 2026 & +17 months & May 2027 & +11 months & May 2028 & +4 months & Oct 2028 \\
\hline Reaches inventory of 300 million EVs & Mar 2024 & +14 months & May 2025 & +9 months & Mar 2026 & +4 months & Jul 2026 \\
\hline
\end{tabular}

Table C2

Milestones compared for functions with 1200 million and 800 million saturation

\begin{tabular}{|c|c|c|c|c|}
\hline & $\mathrm{L}=1200$ million & $\mathrm{L}=1200$ million & $\mathrm{L}=1200$ million & $\mathrm{L}=1200$ million \\
\hline \multirow[t]{2}{*}{ Reaches inflection point } & Jan 2026 & May 2027 & May 2028 & Oct 2028 \\
\hline & $\begin{array}{l}\mathrm{L}=900 \text { million } \\
-6 \text { months }\end{array}$ & $\begin{array}{l}\mathrm{L}=900 \text { million } \\
-6 \text { months }\end{array}$ & $\begin{array}{l}\mathrm{L}=900 \text { million } \\
-4 \text { months }\end{array}$ & $\begin{array}{l}\mathrm{L}=900 \text { million } \\
-5 \text { months }\end{array}$ \\
\hline \multirow[t]{2}{*}{ Reaches inflection point } & Jul 2025 & Nov 2026 & Jan 2028 & Feb 2028 \\
\hline & $\mathrm{L}=1200$ million & $\mathrm{L}=1200$ million & $\mathrm{L}=1200$ million & $\mathrm{L}=1200$ million \\
\hline \multirow[t]{2}{*}{ Reaches inventory of 300 million EVs } & Mar 24 & May 25 & Mar 2026 & Jul 26 \\
\hline & $\begin{array}{l}\mathrm{L}=900 \text { million } \\
+2 \text { months }\end{array}$ & $\begin{array}{l}\mathrm{L}=900 \text { million } \\
+3 \text { months }\end{array}$ & $\begin{array}{l}\mathrm{L}=900 \text { million } \\
+4 \text { months }\end{array}$ & $\begin{array}{l}\mathrm{L}=900 \text { million } \\
+3 \text { months }\end{array}$ \\
\hline Reaches inventory of 300 million EVs & May 2024 & Aug 2025 & Jul 2026 & Oct 2026 \\
\hline
\end{tabular}

\section{Appendix D. References for Table 2}

1) IEA International Energy Agency, 2019. Fuel Economy in Major Car Markets [WWW Document]. URL https:// webstore.iea.org/download/direct/2458?fileName=Fuel_ Economy_in_Major_Car_Markets.pdf; Lge = liters of gasoline equivalent\%22 (accessed 12.2.19).

2) OECD, 2019. Compare your country - Electricity [WWW Document]. URL http://www.compareyourcountry.org/ climate-policies?cr $=$ oecd\&lg $=$ en\&page $=2 \&$ visited $=1$ (accessed 11.18.19).

3) Budget Direct, 2019. Average kilometers travelled per day/ per year in Australia [WWW Document]. URL https://www. budgetdirect.com.au/car-insurance/research/averagekilometers-driven.html\#: :targetText = Average kilometers travelled,day in Australia in 2018 (accessed 11.30.19).

4) Enerdata, 2019. Change in distance travelled by car [WWW Document]. Odyssee-Mure. URL https://www.odyssee-mure. eu/publications/efficiency-by-sector/transport/distancetravelled-by-car.html (accessed 11.30.19).

5) Schoefs, S., 2015. Average used car in Belgium is 8-year-old VW with 116,000 km [WWW Document]. Fleet Eur. URL https://www.fleeteurope.com/en/news/average-used-carbelgium-8-year-old-vw-116000-km?a = SSC01\&t\%5B0\% 5D $=$ CarPass \&curl $=1$ (accessed 11.30.19).

6) Tadano, Y.S., Mazza, R.A., Tomaz, E., 2011. Evaluation of Air Quality: Simulation of Air Pollutants Dispersion in Paulinia Brazil) Using ISCST3, in: Proceedings of the 21st Brazilian Congress of Mechanical Engineering. ABCM, Natal, RN, Brazil.

7) ahainsurance, 2019. What's the average mileage per year in Canada? [WWW Document]. URL https://www. ahainsurance.ca/car-insurance/average-mileage-per-yearcanada/\#: :targetText = According to Natural Resources Canada\%2C Office of Energy Resources\%2C the,with only 13\% 2C100 km travelled (accessed 11.30.19).

8) Cox, W., 2019. Average Chinese car travels as much as American car [WWW Document]. New Geogr. URL https:// www.newgeography.com/content/006420-average-chinesecar-travels-much-american-car (accessed 11.30.19).

9) Statistical Yearbook, 2012. Transport [WWW Document]. URL https://www.dst.dk/Site/Dst/Udgivelser/GetPubFile. aspx?id=16251\&amp;sid=13tra (accessed 11.28.19).
10) Autoalan Tiedotuskeskus, 2014. Finnish Road Network and Its Use [WWW Document]. URL http://www.aut.fi/en/road_ transport/road_transport_in_finland\#: :targetText = The total mileage in Finland,54\%2C000 million kilometres per year (accessed 11.29.19).

11) Enerdata, 2019. Change in distance travelled by car [WWW Document]. Odyssee-Mure. URL https://www.odyssee-mure. eu/publications/efficiency-by-sector/transport/distancetravelled-by-car.html (accessed 11.30.19).

12) Enerdata, 2019. Change in distance travelled by car [WWW Document]. Odyssee-Mure. URL https://www.odyssee-mure. eu/publications/efficiency-by-sector/transport/distancetravelled-by-car.html (accessed 11.30.19).

13) Transport Department, 2017. The Annual Traffic Census 2016 [WWW Document]. URL https://www.td.gov.hk/ filemanager/en/content_4875/annual traffic census 2016.pdf (accessed 11.30.19).

14) Statista, 2014. Average annual mileage of passenger cars in India as of December 2014 (in kilometers) [WWW Document]. URL https://www.statista.com/statistics/611800/ passenger-passenger-car-annual-mileage/(accessed 11.30.19).

15) Enerdata, 2019. Change in distance travelled by car [WWW Document]. Odyssee-Mure. URL https://www.odyssee-mure. eu/publications/efficiency-by-sector/transport/distancetravelled-by-car.html (accessed 11.30.19).

16) Statista, 2014. Distribution of passenger car average usage per year in Japan as of December 2014 (in kilometers) [WWW Document]. URL https://www.statista.com/ statistics/645317/japan-share-passenger-car-traveldistance/(accessed 11.30.19).

17) OECD, 2019a. Road Safety Annual Report 2019-Korea [WWW Document]. URL https://www.itf-oecd.org/sites/default/files/ korea-road-safety.pdf (accessed 11.29.19).

18) Enerdata, 2019. Change in distance travelled by car [WWW Document]. Odyssee-Mure. URL https://www.odyssee-mure. eu/publications/efficiency-by-sector/transport/distancetravelled-by-car.html (accessed 11.30.19).

19) Statistisk sentralbyra, 2019. Road traffic volumes [WWW Document]. URL https://www.ssb.no/en/transport-ogreiseliv/statistikker/klreg (accessed 11.28.19). 
20) OECD, 2019b. Passenger transport [WWW Document]. URL https://data.oecd.org/transport/passenger-transport.htm (accessed 12.1.19).

21) Autostat, 2019. Average car mileage in Russia is $17,500 \mathrm{~km}$ per year [WWW Document]. URL https://eng.autostat.ru/ news/17121/www.autostat.ru/www.autostat.ru/(accessed 11.30.19).

22) Writer, S., 2017. How to know when to sell or trade-in your car in South Africa [WWW Document]. Businesstech. URL https://businesstech.co.za/news/motoring/160779/how-toknow-when-to-sell-or-trade-in-your-car-in-south-africa/ (accessed 12.1.19).

23) Enerdata, 2019. Change in distance travelled by car [WWW Document]. Odyssee-Mure. URL https://www.odyssee-mure. eu/publications/efficiency-by-sector/transport/distancetravelled-by-car.html (accessed 11.30.19).

24) ACEA, 2019. Vehicles in use Europe 2018 [WWW Document]. URL https://www.acea.be/uploads/statistic_documents/ ACEA_Report_Vehicles_in_use-Europe_2018.pdf (accessed 11.28.19).

25) Neue Zürcher Zeitung (NZZ), 2002. Schweizer Fahrzeuge fahren pro Jahr 55 Milliarden Kilometer [WWW Document]. URL https://www.nzz.ch/newzzD5GEZYDI-12-1. 419614\#: :targetText = Weniger als einer von zehn,469 Kilometer pro Jahr zurück.\&targetText $=$ Vom Total der gefahrenen Kilometer, zehn Prozent auf den Gütertransport.1.419614\%23: :targetText $=$ Weniger als einer von zehn,469 Kilometer pro Jahr zurück.\&targetText = Vom Total der gefahrenen Kilometer, zehn Prozent auf den Gütertransport (accessed 11.29.19).

26) Lemaire, J., Park, S.C., Wang, K., 2015. The Use of Annual Mileage as a Rating Variable. ASTIN Bull. 46, 39-69. https:// doi.org/10.1017/asb.2015.25

27) Enerdata, 2019. Change in distance travelled by car [WWW Document]. Odyssee-Mure. URL https://www.odyssee-mure. eu/publications/efficiency-by-sector/transport/distancetravelled-by-car.html (accessed 11.30.19).

28) U.S. Department of Transportation (2018). Average Annual Miles per Driver by Age Group [WWW Document]. URL https://www.fhwa.dot.gov/ohim/onh00/bar8.htm (accessed 11.30.19).

\section{References}

Al-Alawi, B.M., Bradley, T.H., 2013. Review of hybrid, plug-in hybrid, and electric vehicle market modeling Studies. Renew. Sustain. Energy Rev. 21, 190-203. https://doi.org/10.1016/j.rser.2012.12.048.

Bloom, N., 2014. Fluctuations in uncertainty. J. Econ. Perspect. 28, 153-176. https:// doi.org/10.1257/jep.28.2.153.

Boretos, G.P., 2007. The future of the mobile phone business. Technol. Forecast. Soc. Change 74, 331-340. https://doi.org/10.1016/j.techfore.2005.11.005.

BP, 2019. BP Energy Outlook - 2019 [WWW Document].

Burns, L.D., 2013. A vision of our transport future. Nature 497, 181-182. https:// doi.org/10.1038/497181a.

Casals, L.C., Martinez-Laserna, E., Amante García, B., Nieto, N., 2016. Sustainability analysis of the electric vehicle use in Europe for $\mathrm{CO} 2$ emissions reduction. J. Clean. Prod. 127, 425-437. https://doi.org/10.1016/j.jclepro.2016.03.120.

Dharmakeerthi, C.H., Mithulananthan, N., Saha, T.K., 2014. Impact of electric vehicle fast charging on power system voltage stability. Int. J. Electr. Power Energy Syst. 57, 241-249. https://doi.org/10.1016/j.ijepes.2013.12.005.

Domingues, J.M., Pecorelli-Peres, L.A., 2013. Electric vehicles, energy efficiency, taxes, and public policy in Brazil. Law Bus. Rev. Am. 19, 55-80.

Dudley, B., 2019. BP Statistical Review of World Energy [WWW Document].

EAFO, 2019. Country detail incentives [WWW Document].

Egbue, O., Long, S., 2012. Critical issues in the supply chain of lithium for electric vehicle batteries. EMJ - Eng. Manag. Jpn. 24, 52-62. https://doi.org/10.1080 10429247.2012 .11431947$.

Eggers, Felix, Eggers, Fabian, 2011. Where have all the flowers gone? Forecasting green trends in the automobile industry with a choice-based conjoint adoption model. Technol. Forecast. Soc. Change 78, 51-62. https://doi.org/10.1016/ j.techfore.2010.06.014.

Electric Vehicle Database, 2019. Energy consumption of full electric vehicles [WWW Document].

Ellingsen, L.A.-W., Singh, B., Strømman, A.H., 2016. The size and range effect: lifecycle greenhouse gas emissions of electric vehicles. Environ. Res. Lett. 11, 1-7. https://doi.org/10.1088/1748-9326/11/5/054010.

Energy Information Administration, 2017. Russia [WWW Document].

EV-Volumes, 2019. EV Sales Worldwide [WWW Document].

Faria, R., Marques, P., Moura, P., Freire, F., Delgado, J., De Almeida, A.T., 2013. Impact of the electricity mix and use profile in the life-cycle assessment of electric vehicles. Renew. Sustain. Energy Rev. 24, 271-287. https://doi.org/10.1016/ j.rser.2013.03.063.

Figenbaum, E., Assum, T., Kolbenstvedt, M., 2015. Electromobility in Norway: Experiences and Opportunities. Res. Transp. Econ 50, 29-38. https://doi.org/ 10.1016/j.retrec.2015.06.004.

Florides, G.A., Christodoulides, P., 2009. Global warming and carbon dioxide through sciences. Environ. Int. 35, 390-401. https://oi.org/10.1016/ j.envint.2008.07.007.

Geroski, P.A., 2000. Models of technology diffusion. Res. Pol. 29, 603-625. https:// doi.org/10.1016/S0048-7333(99)00092-X.

Gnann, T., Plötz, P., Kühn, A., Wietschel, M., 2015. Modelling market diffusion of electric vehicles with real world driving data - German market and policy options. Transport. Res. Part A Policy Pract 77, 95-112. https://doi.org/10.1016/ j.tra.2015.04.001.

Government of Canada, 2019. Electricity facts [WWW Document], Nat. Resour. Canada.

Government of Hong Kong, 2015. Report on the Public Consultation on Future Fuel Mix for Electricity Generation in Hong Kong [WWW Document].

Government of NCT of Delhi, 2016. Budget 2016-2017 [WWW Document].

Government of Taiwan, 2019. National Statistics [WWW Document].

Hao, H., Ou, X., Du, J., Wang, H., Ouyang, M., 2014. China's electric vehicle subsidy scheme: rationale and impacts. Energy Pol. 73, 722-732. https://doi.org/ 10.1016/j.enpol.2014.05.022.

Higgins, A., Paevere, P., Gardner, J., Quezada, G., 2012. Combining choice modelling and multi-criteria analysis for technology diffusion: an application to the uptake of electric vehicles. Technol. Forecast. Soc. Change 79, 1399-1412. https:// doi.org/10.1016/j.techfore.2012.04.008.

Huo, H., Cai, H., Zhang, Q., Liu, F., He, K., 2015. Life-cycle assessment of greenhouse gas and air emissions of electric vehicles: a comparison between China and the U.S. Atmos. Environ. Times 108, 107-116. https://doi.org/10.1016/ j.atmosenv.2015.02.073.

IEA, 2019a. Fuel Economy in Major Car Markets [WWW Document], Glob. Fuel Econ. Initiat. - Int. Energy Agency.

IEA, 2019b. Brazil [WWW Document], Key energy Stat. 2018.

IEA, 2019c. World energy statistics 2019 [WWW Document].

IEA IA-HEV, 2018. Annual Report 2017: Hybrid and Electric Vehicles - The Electric Drive Automates [WWW Document].

IPPC, 2014. Emission Factors for Greenhouse Gas Inventories [WWW Document].

Jensen, A.F., Cherchi, E., Mabit, S.L., de Dios Ortúzar, J., 2017. Predicting the potential market for electric vehicles. Transp. Sci. 51, 427-440. https://doi.org/10.1287/ trsc.2015.0659.

Lieven, T., 2015. Policy measures to promote electric mobility - a global perspective. Transport. Res. Part A Policy Pract 82, 78-93. https://doi.org/10.1016/ j.tra.2015.09.008.

Lieven, T., Mühlmeier, S., Henkel, S., Waller, J.F., 2011. Who will buy electric cars? An empirical study in Germany. Transp. Res. Part D Transp. Environ. Times 16, 236-243. https://doi.org/10.1016/j.trd.2010.12.001.

Liu, J., 2019. China's renewable energy law and policy: a critical review. Renew. Sustain. Energy Rev. 99, 212-219. https://doi.org/10.1016/j.rser.2018.10.007.

MarkLines, 2019. Vehicle Sales data [WWW Document].

Massiani, J., Gohs, A., 2015. The choice of Bass model coefficients to forecast diffusion for innovative products: an empirical investigation for new automotive technologies. Res. Transp. Econ 50, 17-28. https://doi.org/10.1016/ j.retrec.2015.06.003.

Meade, N., Islam, T., 2006. Modelling and forecasting the diffusion of innovation - a 25-year review. Int. J. Forecast. 22, 519-545. https://doi.org/10.1016/ j.ijforecast.2006.01.005.

Milne, R., 2017. Reality of subsidies drives Norway's electric car dream [WWW Document], Financ. Times.

Ministry of Economy Trade and Industry, 2017. Japan's Energy [WWW Document].

Muller, E., Mahajan, V., 1979. Innovation diffusion and new product growth models in marketing. J. Mark 43, 55-68.

Nanaki, E.A., Koroneos, C.J., 2013. Comparative economic and environmental analysis of conventional, hybrid and electric vehicles - the case study of Greece. J. Clean. Prod. 53, 261-266. https://doi.org/10.1016/j.jclepro.2013.04.010.

Norge, Energifakta, 2019. Electricity production [WWW Document].

OECD, 2013. Passenger Car [WWW Document], Gloss. Stat. Terms.

OECD, 2019. Compare your country - Electricity [WWW Document].

OECD/IEA, 2019. Global EV Outlook 2019 Scaling-up the transition to electric mobility. OECD iea.org 232.

OICA, 2018. Sales of new vehicles 2005-2017 [WWW Document], Organ. Int. des Constr. d'Automobiles.

OICA, 2019. 2018 Production Statistics [WWW Document].

Onat, N.C., Kucukvar, M., Tatari, O., 2014. Towards life cycle sustainability assessment of alternative passenger vehicles. Sustainability 6, 9305-9342. https:// 
16

N. Rietmann et al. / Journal of Cleaner Production 261 (2020) 121038

doi.org/10.3390/su6129305.

Pieltain Fernández, L., Gómez San Román, T., Consent, R., Mateo Domingo, C. Frías, P., 2011. Assessment of the impact of plugin electric vehicles on distributton networks. IEEE Trans. Power Syst. 26, 206-213. https://doi.org/10.1109/ TPWRS.2010.2049133.

Dian, L., Soopramanien, D., 2014. Using diffusion models to forecast market size in emerging markets with applications to the Chinese car market. J. Bus. Res. 67, 1226-1232. https://doi.org/10.1016/j.jbusres.2013.04.008.

Rezvani, Z., Jansson, J., Bodin, J., 2015. Advances in consumer electric vehicle adoption research: a review and research agenda. Transp. Res. Part D Transp. Environ. Times 34, 122-136. https://doi.org/10.1016/j.trd.2014.10.010.

Rietmann, N., Leven, T., 2019. How policy measures succeeded to promote electric mobility - worldwide review and outlook. J. Clean. Prod. 206, 66-75. https:// doi.org/10.1016/j.jclepro.2018.09.121.

Shaken, S.A., Cohen, A.P., 2013. Carsharing and personal vehicle services: worldwide market developments and emerging trends. Int. J. Sustain. Transp 7, 5-34. https://doi.org/10.1080/15568318.2012.660103.

Shakun, J.D., Clark, P.U., He, F., Marcott, S.A., Mix, A.C., Lu, Z., Otto-Bliesner, B., Schmittner, A., Bard, E., 2012. Global warming preceded by increasing carbon dioxide concentrations during the last deglaciation. Nature 484, 49-54. https:// doi.org/10.1038/nature10915.

Statista, 2019. Car sales (passenger and commercial vehicles) in China from 2009 to April 2019 (in million units) [WWW Document].

Techcrunch, 2019. Tesla, Panasonic modify expansion plans for gigafactory [WWW Document].

Teixeira, A.C.R., Sodré, J.R., 2018. Impacts of replacement of engine powered vehicles by electric vehicles on energy consumption and $\mathrm{CO} 2$ emissions. Transp. Res.
Part D Transp. Environ. Times 59, 375-384. https://doi.org/10.1016/ j.trd.2018.01.004.

The World Bank, 2019. Hong Kong SAR, China [WWW Document], Data.

To, W.M., Lee, P.K.C., 2014. Diffusion of ISO 14001 environmental management system: global, regional and country-level analyses. J. Clean. Prod. 66, 489-498. https://doi.org/10.1016/j.jclepro.2013.11.076.

To, M., 2019. China has been slashing its electric car subsidies. That could backfire [WWW Document], CNN Bus.

Union of Concerned Scientists, 2019. Electric Vehicle Battery: Materials, Cost, Lifespan [WWW Document].

van der Steen, M., van Schelven, R.M., Hotter, R., van Twist, M.J.W., van Deventer, P., 2015. EV policy compared: an international comparison of governments' policy strategy towards E-mobility. In: Filho, W.L., Kotter, R. (Eds.), E-mobility in Europe: Trends and Good Practice. Springer, pp. 27-53. Cham.

Wu, Z., Wang, M., Zheng, J., Sun, X., Zhao, M., Wang, X., 2018. Life cycle greenhouse gas emission reduction potential of battery electric vehicle. J. Clean. Prod. 190, 462-470. https://doi.org/10.1016/j.jclepro.2018.04.036.

Yang, Y., Williams, E., 2009. Logistic model-based forecast of sales and generation of obsolete computers in the U.S. Technol. Forecast. Soc. Change 76, 1105-1114. https://doi.org/10.1016/j.techfore.2009.03.004.

Zhu, G., Hein, C.T., Ding, Q., 2017. Case Study - China's regulatory impact on electric mobility development and the effects on power generation and the distribution grid. In: Liebl, J. (Ed.), Grid Integration of Electric Mobility: 1st International ATZ Conference. Springer, Wiesbaden, pp. 13-29.

Riemann, S., Grunwald, A., Schebek, L., Müller, D.B., Weill, M., 2013. The future of mobility and its critical raw materials. Rev. Metall. Cab. D'Informations Tech 110, 47-54. https://doi.org/10.1051/metal/2013052. 